\title{
Measurement of ambient aerosols in northern Mexico City by single particle mass spectrometry
}

\author{
R. C. Moffet ${ }^{1}$, B. de Foy ${ }^{2,3}$, L. T. Molina ${ }^{2,4}$, M. J. Molina ${ }^{1}$, and K. A. Prather ${ }^{1}$ \\ ${ }^{1}$ University of California, San Diego, La Jolla, California, USA \\ ${ }^{2}$ Molina Center for Energy and the Environment (MCE2), La Jolla, California, USA \\ ${ }^{3}$ Saint Louis University, St. Louis, Missouri, USA \\ ${ }^{4}$ Massachusetts Institute of Technology, Cambridge, Massachusetts, USA
}

Received: 18 April 2007 - Published in Atmos. Chem. Phys. Discuss.: 11 May 2007

Revised: 9 May 2008 - Accepted: 2 July 2008 - Published: 5 August 2008

\begin{abstract}
Continuous ambient measurements with aerosol time-of-flight mass spectrometry (ATOFMS) were made in an industrial/residential section in the northern part of Mexico City as part of the Mexico City Metropolitan Area-2006 campaign (MCMA-2006). Results are presented for the period of 15-27 March 2006. The submicron size mode contained both fresh and aged biomass burning, aged organic carbon (OC) mixed with nitrate and sulfate, elemental carbon (EC), nitrogen-organic carbon, industrial metal, and inorganic $\mathrm{NaK}$ inorganic particles. Overall, biomass burning and aged OC particle types comprised $40 \%$ and $31 \%$, respectively, of the submicron mode. In contrast, the supermicron mode was dominated by inorganic $\mathrm{NaK}$ particle types (42\%) which represented a mixture of dry lake bed dust and industrial $\mathrm{NaK}$ emissions mixed with soot. Additionally, aluminosilicate dust, transition metals, OC, and biomass burning contributed to the supermicron particles. Early morning periods (2-6 a.m.) showed high fractions of inorganic particles from industrial sources in the northeast, composed of internal mixtures of $\mathrm{Pb}, \mathrm{Zn}, \mathrm{EC}$ and $\mathrm{Cl}$, representing up to $73 \%$ of the particles in the $0.2-3 \mu \mathrm{m}$ size range. A unique nitrogencontaining organic carbon (NOC) particle type, peaking in the early morning hours, was hypothesized to be amines from local industrial emissions based on the time series profile and back trajectory analysis. A strong dependence on wind speed and direction was observed in the single particle types that were present during different times of the day. The early morning (3:30-10 a.m.) showed the greatest contributions from industrial emissions. During mid to late mornings (711 a.m.), weak northerly winds were observed along with the
\end{abstract}

Correspondence to: K. A. Prather (kprather@ucsd.edu) most highly aged particles. Stronger winds from the south picked up in the late morning (after 11 a.m.), resulting in a decrease in the concentrations of the major aged particle types and an increase in the number fraction of fresh biomass particles. The highest wind speeds were correlated with the highest number fraction of fresh biomass particles (up to $76 \%$ of the submicron number fraction) when winds were coming directly from fires that were located south and southeast of the city based on MODIS fire count data. This study provides a unique clock of hourly changes in single particle mixing state and sources as a function of meteorology in Mexico City. These new findings indicate that biomass burning and industrial emissions can make significant contributions to primary particle loadings in Mexico City that are strongly coupled with local meteorology.

\section{Introduction}

The Mexico City Metropolitan Area (MCMA) is a megacity with a unique mixture of air pollutants from a variety of sources. High levels of criteria pollutants are a product of the city's high population density, meteorology, and unique geographical location. Both gas and particle phase contaminants are generated that degrade human health and affect climate and visibility. A voluminous body of literature has resulted from studies of pollutants in the MCMA, with research focusing on a wide range of topics that include health effects, gas and particle phase measurements, modeling, economics and policy (Raga et al., 2001; Molina and Molina, 2002). The basic approach has been to use Mexico City as a case study of air pollution mitigation while major advances continue to improve the regional air quality.

Published by Copernicus Publications on behalf of the European Geosciences Union. 
To help impose regulatory measures that will decrease particulate matter (PM) pollution in Mexico City, scientists and policy makers need a better understanding of the spatial and temporal variability of the sources, size distribution, and chemical composition of the ambient aerosol. Knowledge of these parameters enables well-guided strategies for decreasing the PM fraction that is suspected to be the most harmful to human health. Prior to the development of the Automatic Ambient Air Quality Monitoring Network (RAMA) measurements that began in the mid 1980s, there were very few detailed measurements of particulate matter chemical composition in Mexico City. From the late 1980s to present, a number of research groups measured PM chemical composition in Mexico City by using filters to collect PM followed by analysis with Proton Induced X-Ray Emission (PIXE) (Miranda et al., 1992; Aldape et al., 1996; Aldape et al., 1996; Cahill et al., 1996; Miranda et al., 1998; Flores et al., 1999; Miranda et al., 2004). Flores (1999) showed increased concentrations of lead, copper and zinc existed in the northern (industrial) part of the city. These results were further corroborated by other results from the sampling period (Mugica et al., 2002).

In the late 1990s, as part of the Aerosol and Visibility Evaluation Research (IMADA-AVER) campaign, Chow and co-workers measured the chemical composition of $\mathrm{PM}_{2.5}$ and $\mathrm{PM}_{10}$ at a variety of sites using filter based techniques while also publishing complementary results characterizing the chemical composition of fugitive dust sources (Chow et al., 2002; Chow et al., 2002; Vega et al., 2002). Moya and co-workers examined the gas-particle equilibrium of ammonium and nitrate during the same campaign for purposes of evaluating thermodynamic models (Moya et al., 2001). They followed up those studies with size resolved measurements focusing on ammonium and sulfate from winter of 2000 to fall of 2001, but also included measurements of other cations (Moya et al., 2003). From January to February of 2003, Moya and co-workers provided a size-resolved characterization of inorganic species. They found an unexpectedly large concentration of $\mathrm{K}$ particles, which they attributed to dust from the dry lake bed of Texcoco in the northeastern part of the city (Moya et al., 2004).

The most recent and detailed studies of aerosols in Mexico City were carried out during the MCMA-2003 campaign (Baumgardner et al., 2004; Dunn et al., 2004; Jimenez et al., 2004; Jiang et al., 2005; Marr et al., 2006; Molina et al., 2007). Electron microscopy was used to infer the mixing state and transformation of soot particles (Johnson et al., 2005). Chemically resolved $\mathrm{PM}_{2.5}$ mass distributions were obtained using a variety of techniques including Aerosol Mass Spectrometry (AMS), and other filter based techniques (Salcedo et al., 2006). Salcedo et al. (2006) were also able to track mass concentrations of select, non-refractory aerosol components with a higher time resolution than previously reported by Chow et al. (2002a), while showing a general agreement between the two studies. Newer source apportion- ment measurements during the MCMA-2003 campaign were able to classify major sources of particles including industrial emissions using factor analysis (Johnson et al., 2006). Industrial emissions found by Johnston et al. (2006) were well correlated with $\mathrm{Na}$ and $\mathrm{Zn}$ as well as other metals.

Many earlier studies of aerosol size and composition in Mexico City from 1990 to the present day were carried out as a part of major campaigns funded through an international effort (Molina et al., 2007). Prior to 2006, there were three major research initiatives that measured aerosol physico-chemical properties: The Mexico City Air Quality Research Initiative (MARI), IMADA-AVER and MCMA2003. The current effort: MILAGRO (Megacity Initiative: Local and Global Research Observations) is the largest to date representing the collaboration of over 400 scientists, from more than 120 institutions. A component of MILAGRO, MCMA-2006, with cooperation from NSF, DOE and a variety of Mexican and European agencies, represents an effort to characterize boundary layer emissions within the MCMA. On-line single particle mass spectrometry represented a new approach for studying air quality in Mexico City during MCMA-2006. The single particle results presented in this manuscript provide unique insights into the sources and processes contributing to the aerosol concentrations.

\section{Experimental}

\subsection{Sampling site - T0}

The ATOFMS instrument was located at the Instituto Mexicano del Petroleo (IMP) in the northern part of Mexico City $\left(19^{\circ} 29^{\prime} 23.60^{\prime \prime} \mathrm{N}, 99^{\circ} 08^{\prime} 55.60^{\prime \prime} \mathrm{W}\right)$. This was one of the three supersites selected for the MILAGRO measurement campaign to characterize the transport of emissions from the urban areas in the MCMA to the surrounding regions. Figure 1 shows the geographical location of the IMP site, referred as T0 (urban site). Measurements were located in a secondary structure on top of a five-story building. Sampling lines were placed $>3 \mathrm{~m}$ above the building's roof to minimize the effects of sampling from the building ventilation exhaust ports. To the north was an $800 \mathrm{~m}$ high mountain, Pico Tres Padres, that served to block most of the winds coming from the north. Industrialized areas existed to the north, while residential areas were located to the east and south. The dry lake bed Lake Texcoco was located to the east. A busy roadway was also located on the east side of the site with traffic jams during most of the day and street vendors cooking primarily during the morning and afternoon.

\subsection{ATOFMS measurements and clustering analysis}

The ATOFMS provides real-time size and chemical composition data for single aerosol particles. The specific instrument used in Mexico City is described by Gard et al. (1997). 
Aerosol particles are drawn through a nozzle-type inlet where the gas undergoes a supersonic expansion, and the particles are accelerated to a specific terminal velocity depending on their aerodynamic size. Particle velocity is determined by measuring the time-of-flight between two $50 \mathrm{~mW}$ diode pumped, solid state, frequency doubled Nd:YAG lasers operating at $532 \mathrm{~nm}$. The single-particle scattering intensities from the two light scattering channels were acquired and saved along with the other single particle size and chemistry data as described by Moffet et al. (2005). Particle size is calculated from the measured speed using a calibration curve generated with known sizes of standard polystyrene latex spheres. The speed of the particle is also used to time the arrival of the particle in the ion source region of the dualpolarity time-of-flight mass spectrometer. Once the particle is in the source region, a frequency quadrupled Nd:YAG laser operating at $266 \mathrm{~nm}$ with a typical pulse energy of $1.2 \mathrm{~mJ}$ desorbs and ionizes each particle. The ATOFMS measures both the positive and negative mass spectra of each particle simultaneously.

The ATOFMS has wide dynamic range (WDR) capabilities. This is accomplished by taking the two signals from the two mass spectra being measured (positive and negative ion) and splitting them into an attenuated $(30 \mathrm{~dB})$ and non-attenuated channel, making four signals in total. The ATOFMS was operated from 6-29 March 2006. Due to damage incurred during shipment, from 6 March 2006 19:00:01 to 13 March 2006 16:00:01, the instrument was operated without the negative wide dynamic range channel. Thus, the results in this paper focus on the WDR period of the study between 15-27 March 2006.

A total of 1 million particles were sized and chemically analyzed with the ATOFMS. The typical percentage of particles producing both size and chemical information was 50\%; of these particles, $88 \%$ produced both positive and negative ion spectra. This percentage showed little variation over the study, indicating chemical matrix effects did not result in any major undetected particle types (Wenzel et al., 2003). Data from the ATOFMS were imported into a Matlab database program known as YAADA (www.yaada.org). Once in the Matlab database, the particles were split into two size groups: sub and super-micron having wide dynamic range. A subset of 24000 particles from each size group were separately classified using ART-2a, a clustering algorithm (Song et al., 1999), run with a vigilance factor of 0.80 and a learning rate of 0.05 . The clusters resulting from each analysis were matched to the rest of the particles in the complete dataset. In order to classify 933000 out of 1 million particles, 60 sub-micron and 200 super-micron clusters (for each of the size groups) accounted for $88 \%$ of the chemically analyzed particles. The unclassified particles made up a large number of sparsely populated clusters. The unclassified particles did not have any major temporal spikes indicating that the original number of particles given to ART-2a was sufficient. The particle clusters resulting from the ART-2a analysis were

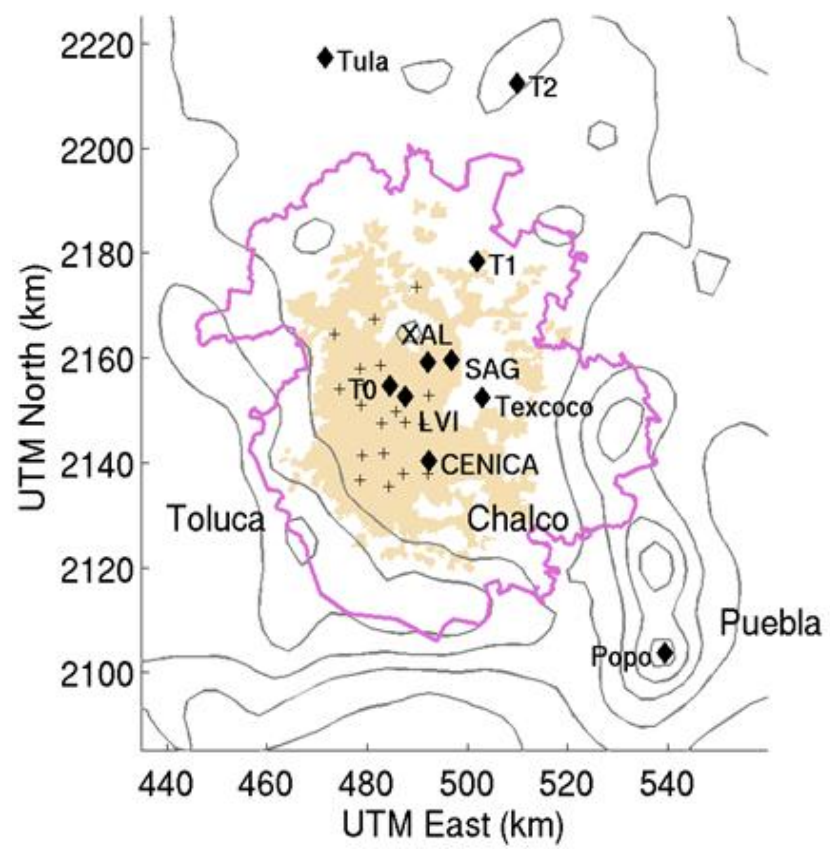

Fig. 1. A map of the Mexico City Metropolitan Area (MCMA). The site at which these measurements were carried out was called T0, and was located at the Instituto Mexicano Del Petroleo (IMP). RAMA sites are shown as the + symbol. The political border of the MCMA as of 2003 is in pink and urban areas (as of 1995) are in beige. Terrain contours are every $500 \mathrm{~m}$.

grouped by hand into 15 general particle types based on the major ion peaks in their mass spectra. The uncertainties of all of the results presented here would mainly result from counting statistics. For the summary plots presented, the uncertainties (non-systematic errors) are normally less than $1 \%$ because the counts for these particle types were typically quite high (i.e. at least 1000 particles per type).

\section{Results and discussion}

For the 3.5 weeks that the ATOFMS operated at the T0 site, unique anthropogenic particle types and mixing states were observed in northern Mexico City that have not been observed in such high abundance in previous ATOFMS studies conducted in other parts of the world. These unique particle types primarily contained metals (e.g. $\mathrm{Pb}, \mathrm{Zn}, \mathrm{Cu}, \mathrm{Ag}$ ) and organic-nitrogen species. The majority of particles in the submicron mode were identified as biomass/biofuel burning $(40 \%)$ and aged OC (31\%), internally mixed with oxidized OC markers (i.e. $\mathrm{m} / \mathrm{z} 43$ ), nitrate, sulfate, and ammonium. In the coarse (super-micron) mode, inorganic dust particle types dominated. For all particle types, hourly time series (Sect. 3.4) and chemically resolved size distributions were obtained (Sect. 3.2). Average diurnal trends show 


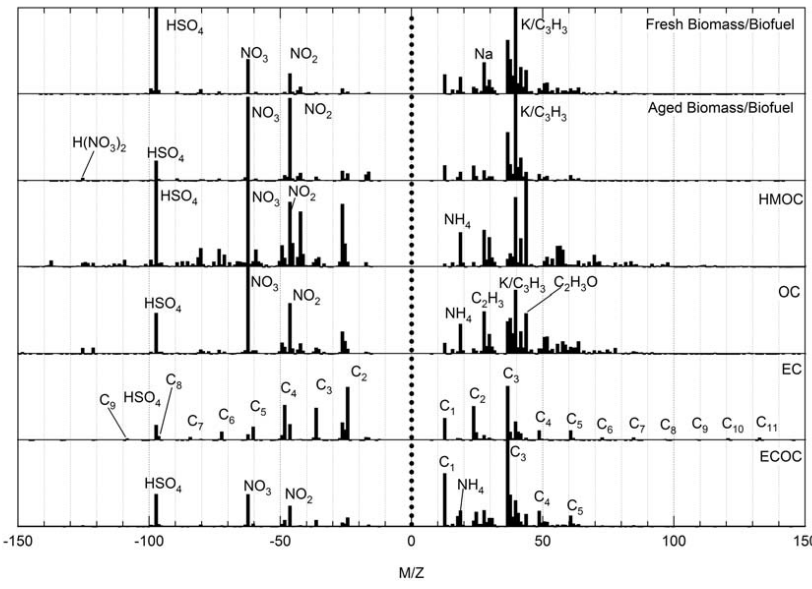

Fig. 2a. Average spectra of single particle types as determined with the ART-2a clustering algorithm. The particle types shown here were the major types detected in the submicron size mode.

industrial emissions primarily occurring in the early morning, and biomass and OC particles making the largest contributions to the aerosol fraction during the early morning to late afternoon hours. To identify possible source regions, a concentration field analysis was performed by combining ATOFMS time series with stochastic Lagrangian back trajectories (Sect. 3.5).

\subsection{Mass spectral analysis of the major particle types}

The average mass spectra for the major single particle types are displayed in Fig. 2. In the submicron size mode, the top three ranked submicron particle clusters were 1) fresh biomass burning, 2) aged OC with ammonium, sulfate, and nitrate, and 3) aged biomass particles with nitrate, ammonium, oxidized $\mathrm{OC}$, and nitrate. Other common submicron types include $\mathrm{NaK}$, amines, and EC particles. Nitrate $\left({ }^{-46} \mathrm{NO}_{2}^{-}\right.$and $\left.{ }^{-62} \mathrm{NO}_{3}^{-}\right)$was detected in most of the negative ion spectra, indicating a significant amount of secondary processing. Other secondary markers in the positive ion spectra included ${ }^{18} \mathrm{NH}_{4}^{+}$as well as ${ }^{43} \mathrm{C}_{2} \mathrm{H}_{3} \mathrm{O}^{+}$, a marker used to indicate oxidized organic species in the ATOFMS. The number fraction of particles mixed with ammonium, oxidized organic species, and nitrate tended to peak between 10 a.m.-12 p.m. LT. Fine mode carbonaceous particles also contained sulfate $\left({ }^{97} \mathrm{HSO}_{4}^{-}\right)$in their negative ion spectra. Coarse (super-micron) mode particle types (AlSi, NaK, Ca Dust) almost all contained secondary species such as nitrate in addition to other species such as ${ }^{35} \mathrm{Cl}^{-}$and ${ }^{79} \mathrm{PO}_{3}^{-}$. The names for the categories presented below are based on the most abundant ion markers that allow them to be assigned to the original (primary) particle source. A discussion of the chemical associations between these primary particle types and other secondary species is given in Sect. 3.3.1 on mixing state.

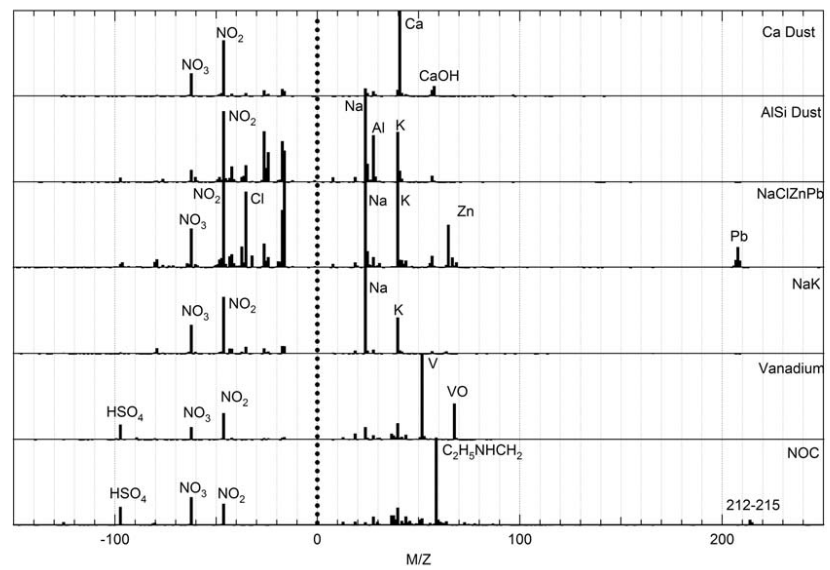

Fig. 2b. Average spectra of single particle types as determined with the ART-2a clustering algorithm. The $m / z$ range is extend to $250 \mathrm{Da}$ compared to Fig. 2a to show important peaks such as $\mathrm{Pb}$ for the industrial types and the unknown markers at 212-215 for the NOC type. Common coarse mode particle types shown here include: $\mathrm{Ca}$, $\mathrm{AlSi}$, and $\mathrm{Na} / \mathrm{K}$. The nitrogen organic carbon (NOC) type was primarily detected in the submicron size mode.

\subsubsection{Carbonaceous particle types}

\section{Biomass/Biofuel burning}

In previous ATOFMS studies, signatures were obtained that can be used for the identification of biomass/biofuel burning particles (Silva et al., 1999; Guazzotti et al., 2003). Particles classified as biomass burning have ${ }^{39} \mathrm{~K}^{+}$as one of the largest peaks in the positive ion mass spectrum. Additionally, the negative ion markers for many of the biomass particles show levoglucosan negative ion fragments at $-45,-59$, and -73 . Many biomass particles also showed the presence of oxidized organic species as indicated by a peak at $m / z 43\left(\mathrm{CH}_{3} \mathrm{CO}^{+}\right)$ as well as ammonium $(m / z 18)$, nitrate $(m / z-62)$, and sulfate $(m / z-97)$. Fresh and aged biomass clusters are split on the basis of nitrate ion intensity, with the aged biomass class having larger nitrate signals than sulfate. Additionally a nitrate cluster ion peak for aged biomass at $m / z=-125$ $\left(\mathrm{H}\left(\mathrm{NO}_{3}\right)_{2}\right)$ was also observed, indicating significant amounts of nitrate. $\mathrm{Na}^{+}$is prominent in some of the biomass/biofuel particles. Particles having organic plus inorganic salt signatures can be emitted as a result of high temperature processes including biomass/biofuel burning, refuse burning, or cooking operations (Silva, 2000). It should be emphasized here that the overall biomass particle signatures detected in Mexico City were derived from previous ATOFMS biomass source tests conducted in our laboratory. These signatures are indicative of biomass burning and do not resemble the major particle types in any other previous ATOFMS source studies of vehicles or collected dust samples (Arimoto et al., 2006; Qin and Prather, 2006; Toner et al., 2006; Shields et al., 2007; Toner et al., 2007; Sullivan et al., 2007). 


\section{$O C$}

Organic carbon (OC) particles were the second most abundant submicron particle type observed during this study. These particles are similar to those detected in other ATOFMS field studies (Noble et al., 1996; Liu et al., 2003; Pastor et al., 2003) and vehicle source characterization studies (Sodeman et al., 2005; Toner et al., 2006). OC particles are typified by hydrocarbon ion series that start with the base carbon peak ${ }^{12 n} \mathrm{C}_{n}^{+}$. In Fig. 2a, two of the major OC peaks are identified as ${ }^{27} \mathrm{C}_{2} \mathrm{H}_{3}^{+}$and ${ }^{43} \mathrm{C}_{2} \mathrm{H}_{3} \mathrm{O}^{+}$. Many spectra also contain a large peak at $m / z 39\left(\mathrm{~K}^{+}\right)$, indicating coagulation between $\mathrm{OC}$ and biomass types or condensation of primary and secondary organic species on biomass seed particles. As discussed below, the majority of the OC particles were heavily processed and contained both secondary organic and inorganic species. This particle type is typically correlated with secondary organic aerosol as measured by other on-line techniques such as the aerosol mass spectrometer (Salcedo et al., 2006).

\section{NaEC}

The NaEC type is characterized by elemental carbon cluster ions at spacing of $12 \mathrm{~m} / z$ units in both the positive and negative ion spectra. This type has a dominant ${ }^{23} \mathrm{Na}^{+}$peak along with a smaller ${ }^{39} \mathrm{~K}^{+}$in the positive ion spectrum; many of these particles also show a $\mathrm{Li}^{+}$peak at $m / z 6$ and 7. In the negative ion spectra, peaks appear for $\mathrm{Cl}^{-}$ $(m / z-35 /-37)$, EC cluster ions, OC, phosphate, and inorganic nitrogen $(m / z-46$ and -62$)$ sulfur species $(m / z-32$, $-80,-96)$. This particle type was most likely produced by industrial emissions and quite possibly related to incineration or refuse burning.

\section{ECOC}

The Elemental Carbon/Organic Carbon (ECOC) type is characterized by a positive ion mass spectrum that is dominated by clusters of carbon atoms. In addition to the major elemental carbon markers, smaller signals occur from OC, nitrate, sulfate, and ammonium. In general, less OC, nitrate, and sulfate are associated with these EC particles in the early morning during the high traffic period (Sect. 3.4.2).

\section{High Mass $O C$}

The high mass organic carbon class was a unique particle type which was distinguishable from other OC types by the presence of hydrocarbon envelopes in the positive ions extending above $100 \mathrm{Da}$. Typically these hydrocarbon envelopes have a $\Delta m / z=14$, which is due to successive losses of a ${ }^{14} \mathrm{CH}_{2}$ group. Although not shown in the figure, the hydrocarbon envelopes can extend out to $m / z=200$ and above. Similar high mass OC particles have been observed in foggy regions with high biomass emissions (Qin et al., 2006). The larger particle sizes, higher molecular weight marker compounds, as well as the fact that they were detected at night suggest these may be processed organic biomass particles.

\section{Vanadium}

Vanadium particles have been identified with other analytical methods as well as single particle mass spectrometry in studies of light duty vehicle (LDV) emissions (Sodeman et al., 2005), industrial urban areas (Noble et al., 1996; Tolocka et al., 2004), and in coal and oil fired power plant emissions (Suarez et al., 2002). Particles containing vanadium produce a very unique mass spectrum with peaks at ${ }^{51} \mathrm{~V}^{+}$and ${ }^{67} \mathrm{VO}^{+}$. Oxalate and vanadium were frequently internally mixed with oxalate anions detected in the negative ion mass spectrum of many vanadium particles at $m / z=-89\left({ }^{89} \mathrm{C}_{2} \mathrm{O}_{3} \mathrm{OH}^{-}\right)$. Secondary sulfate and vanadium are a result of emissions from fossil fuel combustion. Oxalate may be produced by either biomass burning, or VOC oxidation followed by subsequent aqueous phase processing (Chebbi et al., 1996; Morawska et al., 2002). The fraction of the oxalic acid mass formed by cloud processing is currently a topic of research (Ervens et al., 2004; Kanakidou et al., 2005).

\section{Nitrogen-organic carbon (NOC)}

A nitrogen-containing organic carbon (NOC) particle type was detected virtually every morning during the study except during the holiday period (19-20 March). The "NOC" label is based on the large peak at $m / z=58$ which we hypothesize is due to an amine fragment at ${ }^{58} \mathrm{C}_{2} \mathrm{H}_{5} \mathrm{NHCH}_{2}^{+}$which has been identified by ATOFMS and in other laboratory studies (Pitts et al., 1978; Angelino et al., 2001); and a collocated AMS instrument (Aiken et al., 2007). There is also a grouping of small ion peaks at $m / z=212-215$ of unknown identity on almost every NOC particle detected.

\subsubsection{Dust and metallic particle types}

\section{$\mathrm{NaK}$}

The highest fraction of supermicron particles in Mexico City had the positive ion spectrum dominated by ${ }^{23} \mathrm{Na}^{+}$and/or ${ }^{39} \mathrm{~K}^{+}$. These particles were a combination of industrial emissions as well as salt particles from the Texcoco dry lake bed. A large fraction $(87 \%)$ of these particles also contained nitrate $\left({ }^{46} \mathrm{NO}_{2}^{-}\right.$and $\left.{ }^{62} \mathrm{NO}_{3}^{-}\right)$as major peaks in the negative ion mass spectra Significant ion signals were also present from phosphate $\left({ }^{79} \mathrm{PO}_{3}\right)^{-}$and chloride $\left({ }^{35,37} \mathrm{Cl}^{-}\right)$. Coarse mode $\mathrm{Na}$ and $\mathrm{K}$ have been found to be in sea salt, soil dust, biogenic material, and industrial processes (Beddows et al., 2004). Interestingly, many of the NaK particles were strongly associated with $\mathrm{Cl}$ and $\mathrm{EC}$ at night, peaking at 3-4a.m. These $\mathrm{NaK}$ particles showed a strong diurnal pattern with heterogeneous conversion of intense chloride to nitrate ion signals during the daylight hours (6 a.m.-6 p.m.). This gas/particle 


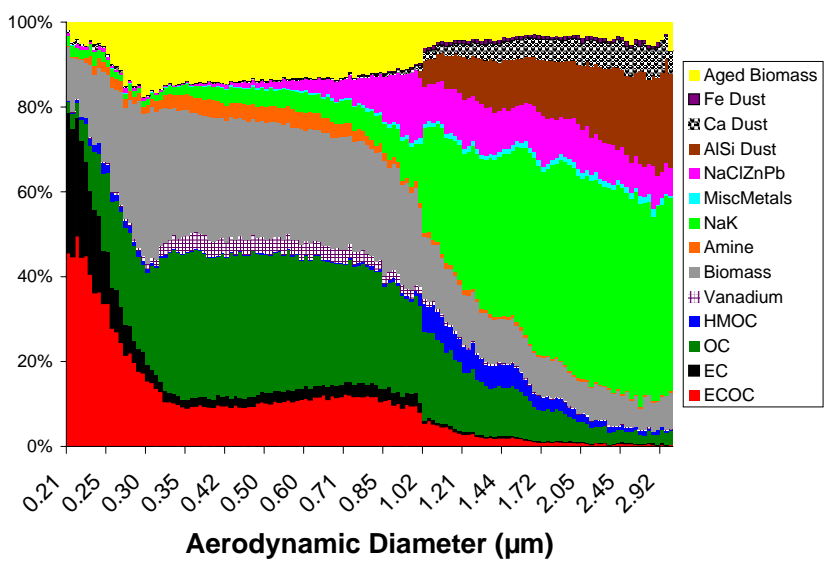

Fig. 3. Size-resolved particle classes by number percentage, showing the contribution of the single particle types for the MCMA2006 campaign.

displacement chemistry is similar to previous ATOFMS observations showing a strong anti-correlation between nitrate and chloride on sea salt particles (Gard et al., 1998). This heterogeneous processing of salt particles, from industry as well as from the dry lake bed, may well have a strong impact on the gas phase concentrations of $\mathrm{NO}_{\mathrm{x}}$, chloride, and other species in the Mexico City region. It will be interesting to compare the ATOFMS results with model predictions to test whether the models are capturing this heterogeneous chloride-nitrate chemistry.

\section{AlSi}

${ }^{27} \mathrm{Al}^{+}$was frequently found to be mixed with ${ }^{23} \mathrm{Na}^{+},{ }^{39} \mathrm{~K}^{+}$ and ${ }^{35} \mathrm{Cl}^{-}$. When $\mathrm{Al}$ was associated with silicon markers ${ }^{60} \mathrm{SiO}_{2}^{-}$and ${ }^{76} \mathrm{SiO}_{3}^{-}$, the particle was placed in the AlSi class. The presence of these peaks suggests that the particle was composed of aluminosilicate species which are common in mineral dust. ${ }^{7} \mathrm{Li}^{+}$was commonly detected in the positive ion mass spectrum of the AlSi type. Mass spectra containing an intense peak at $m / z 56$ with a smaller isotopic peak at $m / z 54$ indicate the presence of ${ }^{56} \mathrm{Fe}^{+}$.

\section{$\mathrm{Ca}$}

At $m / z=40^{40} \mathrm{Ca}^{+}$stands out as the largest peak in the positive ion spectrum accompanied by smaller peaks at $m / z=56$ and 57 due to ${ }^{56} \mathrm{CaO}^{+}$and ${ }^{57} \mathrm{CaOH}^{+}$. Previous studies have described the ability of $\mathrm{CaCO}_{3}$ dust to react with nitric acid to form $\mathrm{Ca}\left(\mathrm{NO}_{3}\right)_{2}$ (Krueger et al., 2004; Laskin et al., 2005). It is likely that the calcium dust shown herein has undergone this heterogeneous reaction as indicated by the negative ion mass spectrum which shows intense markers for nitrite and nitrate at ${ }^{46} \mathrm{NO}_{2}^{-}$and ${ }^{62} \mathrm{NO}_{3}^{-}$. Smaller peaks occur in the positive ion spectrum at $m / z 24$ and 27 due to $\mathrm{Mg}$ and $\mathrm{Al}$, respectively.

\section{$\mathrm{NaClZnPb}$}

In these particles, $\mathrm{Zn}$ is one of the largest contributors to the positive ion spectrum occurring at $m / z=+64,+66,+67$ and +68 . Often internally mixed with $\mathrm{Zn}, \mathrm{Pb}$ ions appear at $m / z+206,+207$, and +208 . Other peaks in the positive ion spectrum include ${ }^{23} \mathrm{Na}^{+}$and ${ }^{39} \mathrm{~K}^{+}$. It has been observed in other studies that $\mathrm{Pb}, \mathrm{Zn}$ and $\mathrm{Na}$ were associated with the industrial areas in northern Mexico City (Miranda et al., 1994; Flores et al., 1999; Chow et al., 2002; Johnson et al., 2006). In addition to nitrate $\left({ }^{46} \mathrm{NO}_{2}^{-}\right.$and $\left.{ }^{62} \mathrm{NO}_{3}^{-}\right)$, chloride $\left({ }^{35} \mathrm{Cl}^{-}{ }^{37} \mathrm{Cl}^{-}\right)$was one of the most abundant ion in the negative spectra. In general, zinc and lead chlorides have relatively low boiling points $\left(732^{\circ} \mathrm{C}\right.$ and $950^{\circ} \mathrm{C}$, respectively), and are emitted in the gas phase of high temperature combustion sources such as waste incinerators (Olmez et al., 1988; Ondov et al., 1998; Hu et al., 2003). Upon cooling, these compounds will condense into the solid phase, forming submicron $\mathrm{Cl}$-containing particles. It should be noted that a significant number of metal rich particles also contributed to the submicron fraction, suggesting many were formed by combustion processes.

\section{Other metal types}

Minor particle types that account for less than $1.3 \%$ of the total particles analyzed during the study contained $\mathrm{Cu}, \mathrm{Fe}$, and miscellaneous metal-containing particles (MiscMetals). The $\mathrm{Cu}$ particle type typically was mixed with $\mathrm{EC}, \mathrm{Pb}, \mathrm{Cl}$, $\mathrm{Na}$ and K. The MiscMetals class contained a combination of different particle types containing various elements including $\mathrm{Mg}, \mathrm{Mn}, \mathrm{Ti}, \mathrm{Cr}$, and Ag.

\subsection{Chemically resolved particle size distributions}

Figure 3 presents number fractions of the size resolved chemical mixing state for the major particle types between 0.2 and $3 \mu \mathrm{m}$ detected with the ATOFMS during MCMA-2006. With the exception of the high mass OC type, which peaked around $1 \mu \mathrm{m}$, carbonaceous particle types were in the submicron size mode, whereas the supermicron particles consisted of inorganic dust and salt particles, a size-composition relationship seen in previous ATOFMS studies (Noble et al., 1996).

The ATOFMS can measure the relative degree of aging of biomass/biofuel particles using the intensity of nitrate $(m / z-62)$ and its associated cluster ions (e.g. $\mathrm{H}\left(\mathrm{NO}_{3}\right)_{2}$ at $m / z-125$ ), allowing segregation of the biomass particles into fresh and aged types. In general, the aged biomass mass spectra showed more intense ion signals for nitrate and oxidized organic species. The time series and a concentration field analysis (CFA - see below) for the fresh and aged biomass particle types showed significant differences between the particle types. The size transmission efficiency of the ATOFMS inlet used for MILAGRO scales as $\mathrm{D}^{-3}$. Thus, 


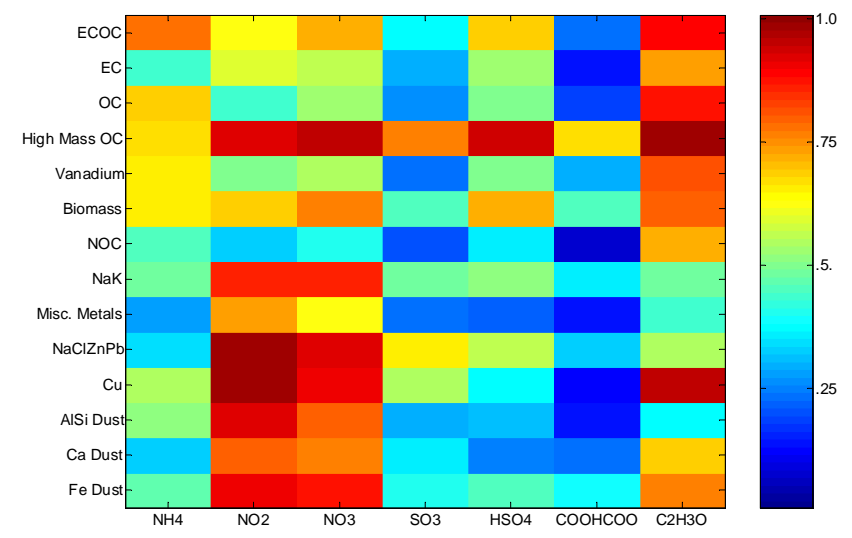

Fig. 4. Mixing state of secondary species on the various single particle types. The secondary species were identified by the peak searching criteria described in Table 1 . The peak searches were applied to the entire dataset and then intersected with the particle classes. The color scale represents the fraction of particles within a single particle type (y-axis) that contain the secondary species ( $\mathrm{x}$-axis).

the unscaled ATOFMS size distributions are equivalent to volume/mass distributions (Allen et al., 2000). The unscaled ATOFMS size distributions of the fresh biomass/biofuel particles showed the mode peaking at $\sim 300 \mathrm{~nm}$, a value consistent with the volume median diameter of $250-300 \mathrm{~nm}$ reported from a number of previous studies of relatively fresh biomass emissions (Reid et al., 2005). The peak of the size distribution for the aged biomass/biofuel particles was $350 \mathrm{~nm}$. This $50 \mathrm{~nm}$ size shift agrees with literature reports of the volume distribution of biomass/biofuel particles that have aged between 1-3 days (Reid et al., 2005). Assuming this size change was due to coating of spherical particles, the shift corresponds to a change in volume of $60 \%$ for the aged biomass particles due to the addition of ammonium, nitrate, primary and secondary organic species, as well as water. However, it should be noted that shape and density effects may also play a role in the apparent size change detected here. It is important to note that as the size of the biomass particles increase, a smaller mass fraction is due to the original biomass core. The more aged biomass particle types showing more secondary components tended to peak in the later morning hours, tracking the more aged OC types. The fresh biomass particle signatures were detected when high wind speeds led to rapid transport from the fires, as shown in MODIS satellite images, to the site during the afternoon periods (see CFA back trajectory analysis discussion in Sect. 3.5).

\subsection{Analysis of mixing state using the peak search method}

In addition to the cluster analysis presented above, a separate peak searching method was employed to highlight trends in the aerosol mixing state of the various particle types. A series
Table 1. Peak searching criteria for secondary species.

\begin{tabular}{ll}
\hline Secondary marker & $m / z$ \\
\hline $\mathrm{NH}_{4}$ & +18 \\
$\mathrm{NO}_{2}$ & -46 \\
$\mathrm{NO}_{3}$ & -62 \\
$\mathrm{SO}_{3}$ & -80 \\
$\mathrm{HSO}_{4}$ & -97 \\
$\mathrm{C}_{2} \mathrm{O}_{3} \mathrm{OH}$ & -89 \\
$\mathrm{C}_{2} \mathrm{H}_{3} \mathrm{O}$ & +43 \\
\hline
\end{tabular}

of markers were selected to represent the different primary and secondary species. The mass/charge $(\mathrm{m} / z)$ values used for primary and secondary species are shown in Tables 1 and 2. All ion intensities were set to be greater than or equal to an absolute peak area ( $\geq 100$ units) that is two times the detection threshold (50 units). To determine which of the selected markers were associated with the various particle types, particles with the species defined in Tables 1 and 2 were intersected with the major particle types derived from the ART-2a clustering analysis (Sect. 3.1). Figures 3 and 4 show the results of these intersections, where the color scale represents the fraction of particles of each major type (y-axis) associated with a particular marker (x-axis).

\subsubsection{Mixing state of secondary species}

The presence of secondary species on the various particle types (Fig. 4) provides an indication of the type of chemical processes the particles have undergone in the atmosphere. The key question is: are there differences in the associations of the major secondary species (e.g. sulfate, nitrate, and ammonium) with each of the major particle types? For instance, the EC and NOC types contain the fewest particles with ammonium, nitrate, and sulfate, indicating that many of these particles were freshly emitted from locations close to T0. As these particles age through condensation and coagulation, they can accumulate other markers to become other particle types such as OC and ECOC. Ammonium is seen to be confined mainly to the submicron ECOC and OC types, whereas coarse mode particle types that contain $\mathrm{NH}_{4}^{+}$are mainly limited to the AlSi and $\mathrm{Cu}$ types. For the AlSi type, the $\mathrm{NH}_{4}^{+}$ does not necessarily come from the atmosphere because it is common to find $\mathrm{NH}_{4}^{+}$in soils (Schlesinger et al., 1992), and therefore may not necessarily be indicative of aging in this particle type.

Nitrate $\left(\mathrm{NO}_{2}^{-}\right.$and $\left.\mathrm{NO}_{3}^{-}\right)$occurs mostly on primary inorganic dust particles in both the sub and super-micron size modes. In the submicron size range, more than $50 \%$ of the fine carbonaceous particles were associated with nitrate and ammonium. As described in Sect. 3.1.2, the coarse NaK dust type showed conversion from $\mathrm{NaK}$ chloride to $\mathrm{NaK}$ 


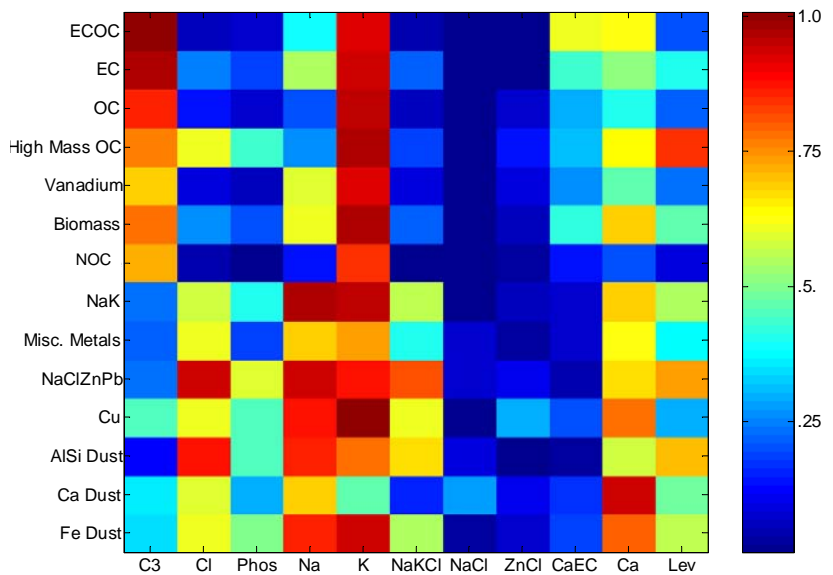

Fig. 5. Mixing state of primary species on the various single particle types. The primary species were identified by the peak searching criteria described in Table 2. The peak searches were applied to the entire dataset and then intersected with the particle classes. The color scale represents the fraction of particles within a single particle type (y-axis) that contain the primary species ( $\mathrm{x}$-axis).

nitrate particles, with nitrate peaking on the particles when the maximum nitrate mass concentrations were observed in the late morning. This heterogeneous displacement process is analogous to the atmospheric processing of sea salt particles observed previously by ATOFMS in marine environments (Gard et al., 1998).

The $\mathrm{NaClZnPb}$ particle types were strongly associated with nitrate $\left(\mathrm{NO}_{2}^{-} / \mathrm{NO}_{3}^{-}\right)$and occurred in both the sub- and supermicron size modes. Given that these industrial metal types were probably freshly emitted, this association suggests that many of these metal-chloride (i.e. $\mathrm{PbCl}, \mathrm{ZnCl}_{2}$ ) particles underwent heterogeneous displacement reactions with $\mathrm{HNO}_{3}$. The nitrate displaced the $\mathrm{Cl}$ originally released in these industrial particles. This cluster groups these two particle types (i.e. fresh and aged) together. A clear time lag occurred as the amount of $\mathrm{Cl}$ initially present when the particles were initially detected decreased and the amount of nitrate increased in these particles later in the morning (Moffet et al., 2008). The organic carbon markers used to highlight mixing with other particle types were chosen to be ${ }^{43} \mathrm{C}_{2} \mathrm{H}_{3} \mathrm{O}^{+}$and $\mathrm{C}_{2} \mathrm{O}_{3} \mathrm{OH}^{-}$(oxalate at $\mathrm{m} / z-89$ ). It is apparent that ${ }^{43} \mathrm{C}_{2} \mathrm{H}_{3} \mathrm{O}$ is mainly associated with the fine mode particles but occurs in over $40 \%$ of the supermicron particles (with the exception of the $\mathrm{NaClZnPb}$ type). This organic carbon likely comes from secondary oxidation reactions and gas-to-particle conversion of organic species. The oxalate marker is an indicator of the presence of oxalic acid. Oxalic acid may be emitted as a part of vehicle exhaust and biomass burning (Kawamura et al., 1987; Chebbi et al., 1996; Falkovich et al., 2005) but most commonly through secondary processes including photochemistry followed by
Table 2. Peak searching criteria for primary species.

\begin{tabular}{llrl}
\hline Primary Species & Marker & $m / z$ & Logical \\
\hline $\mathrm{C}$ & $\mathrm{C}$ & 12 & \\
$\mathrm{Cl}$ & $\mathrm{Cl}$ & -35 & \\
$\mathrm{PO}_{3}$ & $\mathrm{PO}_{3}$ & -79 & \\
$\mathrm{Na}$ & $\mathrm{Na}$ & 23 & \\
$\mathrm{~K}$ & $\mathrm{~K}$ & 39 & \\
$\mathrm{NaKCl}$ & $\mathrm{Na}$ & 23 & \\
& $\mathrm{~K}$ & 39 & And \\
& $\mathrm{Cl}$ & -35 & And \\
$\mathrm{NaCl}$ only & $\mathrm{Na}$ & 23 & \\
& $\mathrm{Cl}$ & -35 & And \\
& $\mathrm{K}$ & 39 & AndNot \\
$\mathrm{Zn}$ not $\mathrm{Pb}$ & $\mathrm{Zn}$ & 64 & \\
& $\mathrm{Zn}$ & 66 & And \\
& $\mathrm{Pb}$ & $206-209$ & AndNot \\
$\mathrm{CaEC}$ & $\mathrm{C}_{3}$ & 36 & \\
& $\mathrm{C}_{4}$ & 48 & And \\
& $\mathrm{C}_{5}$ & 60 & And \\
& $\mathrm{Ca}$ & 40 & And \\
$\mathrm{Ca}$ & $\mathrm{Ca}$ & 40 & \\
$\mathrm{Lev}$ & $\mathrm{CHO}_{2}$ & -45 & Or \\
& $\mathrm{C}_{2} \mathrm{H}_{3} \mathrm{O}_{2}$ & -59 & Or \\
& $\mathrm{C}_{3} \mathrm{H}_{5} \mathrm{O}_{2}$ & -73 & Or \\
\hline
\end{tabular}

condensation, fog processing or aerosol surface reactions (Kawamura et al., 1993; Faust, 1994; Blando et al., 2000; Yao et al., 2002). Oxalate is associated with biomass and vanadium types, as shown in Fig. 4, where 37\% and $45 \%$ of the particles in these classes contain the oxalate marker, respectively.

\subsubsection{Mixing state of primary species}

A marker for $\mathrm{EC}$ or soot, ${ }^{36} \mathrm{C}_{3}^{+}$, was chosen to highlight the distribution of carbon - especially in the non-carbonaceous primary particle types. This marker can come from secondary species as well, but is more commonly detected in primary particles. Fig. 5 shows that the $\mathrm{NaClZnPb}$ and $\mathrm{Cu}$ types are mixed with $\mathrm{C}_{3}^{+}$(EC). This result, combined with the predominately fine mode size distribution (Fig. 3), provides further evidence that the $\mathrm{NaClZnPb}$ and $\mathrm{Cu}$ particles are products of high temperature combustion processes. While ${ }^{36} \mathrm{C}_{3}^{+}$can be used to identify particle classes that are internally mixed with $\mathrm{EC},{ }^{40} \mathrm{Ca}^{+}$can be used to identify unique sources of EC. Source studies indicate that particles containing both $\mathrm{Ca}$ and EC are primarily associated with heavy duty vehicle emissions (Toner et al., 2006). The relative number of elemental carbon with $\mathrm{Ca}$ particles can be determined by searching for the typical EC markers together with $\mathrm{Ca}(\mathrm{CaEC})$. From Fig. 5, about $50 \%$ of the EC is associated with $\mathrm{Ca}$, suggesting diesel vehicle emissions produce a substantial fraction of $\mathrm{EC} /$ soot in this region. 


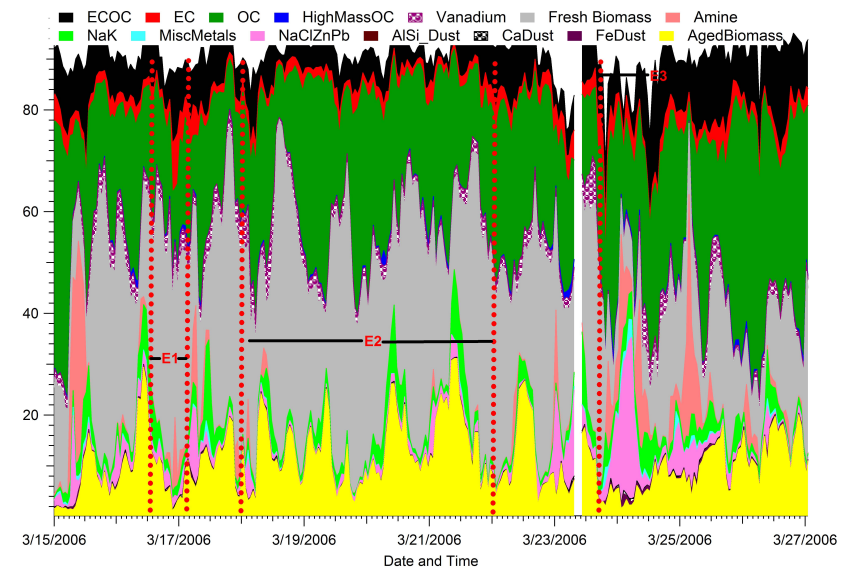

Fig. 6a. Temporal variation of the submicron particle types during MCMA-2006.

Chlorine $(\mathrm{m} / z-35$ and -37$)$ is mainly associated with inorganic particle types. This is supported by Fig. 5 which shows a strong degree of internal mixing between metals, $\mathrm{K}$, $\mathrm{Na}$, and $\mathrm{Cl}$. $\mathrm{Cl}$ is also associated with the AlSi type and moderately associated with the $\mathrm{NaK}$ and $\mathrm{Ca}$ dust particle types. For Ca dust, there is much less $\mathrm{Na}$ and $\mathrm{K}$ associated with $\mathrm{Cl}$ compared to the other inorganic particle classes. A secondary source of $\mathrm{Cl}$ is $\mathrm{HCl}$ formed by heterogeneous displacement from primary particles composed of $\mathrm{NaCl}, \mathrm{KCl}, \mathrm{PbCl}_{2}$, or $\mathrm{ZnCl}_{2}$ which react with acidic (i.e. $\mathrm{HNO}_{3}$ or $\mathrm{H}_{2} \mathrm{SO}_{4}$ gases. Anthropogenic sources of $\mathrm{HCl}$ include coal combustion and incineration of municipal and industrial waste (Graedel et al., 1995). The source of the $\mathrm{HCl}$ in incineration is the combustible plastics, in particular polyvinyl chloride (PVC's). The resulting gas phase $\mathrm{HCl}$ can then partition to other particles. We have recently shown that mixing between $\mathrm{Cl}$ and $\mathrm{Ca}$ can occur through secondary uptake of $\mathrm{HCl}$ (Sullivan et al., 2007). This suggests that for the metals and AlSi dust, the $\mathrm{Cl}$ is primary but for the $\mathrm{Ca}$ dust, the $\mathrm{Cl}$ may be secondary.

Levoglucosan $(\mathrm{m} / \mathrm{z}-45,-59$, and -73$)$ is a known marker for biomass burning aerosols. Levoglucosan is indeed present in biomass burning particles but also in a number of the other particle types. The correlation of Levoglucosan with AlSi Dust is most likely due to an interference of $m / z=-73$ with ${ }^{73} \mathrm{SiO}_{3}^{-}$. This could be due coagulation between biomass burning and other particle types, but it is also possible that some of the other particle types (i.e. $\mathrm{NaK}$ ) were formed by combustion processes. At this stage, we hypothesize that a number of the $\mathrm{NaK}$ and $\mathrm{NaClZnPb}$ types are due to refuse and paper burning which are known producers of levoglucosan. Finally, it is interesting to note that even though there is a general correlation in the time series of the biomass burning aerosols and levoglucosan markers, only about $50 \%$ of the biomass burning aerosols contain levoglucosan markers. It has been reported recently that the amount of levoglu-

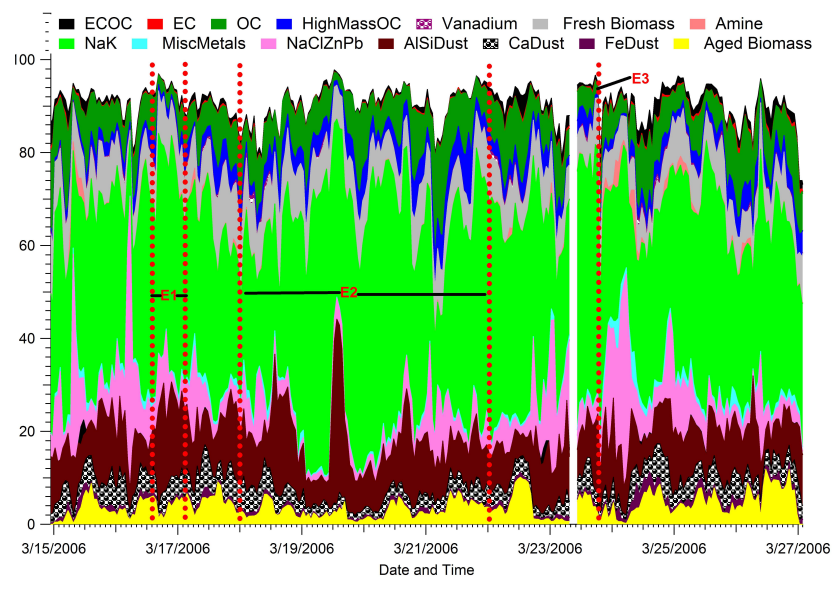

Fig. 6b. Temporal variation of the supermicron particle types during MCMA-2006.

cosan produced depends strongly on the fuel type and burn conditions (Hedberg et al., 2006; Mazzoleni et al., 2007). Thus, the presence (or absence) of levoglucosan could be related to the burn conditions (i.e. flaming vs. smoldering) or the type of fuel (i.e. grass and shrubs vs. pine trees). We plan to explore the different types of biomass/biofuel burning single particle signatures observed with the ATOFMS and determine whether additional insight can be gained as to other biomass/biofuel sources or conditions in a future paper.

As shown in Fig. 5, $\mathrm{K}$ and $\mathrm{Na}$ particles were present in both the coarse and fine mode particles. It is important to note that ${ }^{39} \mathrm{~K}^{+}$ions interfere with organic ion markers (e.g. ${ }^{39} \mathrm{C}_{3} \mathrm{H}_{3}^{+}$). This may explain why a large fraction of the organic carbon particles appear to contain K. However, visual inspection of these particles shows that many of the organic carbon particles also contain $\mathrm{K}$, given the high relative intensity of the $\mathrm{K}^{+}$peak. Biomass particles are a prime example of a submicron particle type that contains $\mathrm{K}$ and organic carbon as an internal mixture. These same mixtures were observed in TEM images acquired during aircraft flights on the Twin Otter above Mexico City (Yokelson et al., 2007)

\subsection{Temporal characteristics of single particle types}

The temporal characteristics of the single particle types can provide a great deal of insight into the origin of the particles. In this section, the temporal profiles for sub- and supermicron particle types are described in detail. Three major events are labeled on the temporal profiles shown in Fig. 6. The first event (E1) was a large dust event where the $\mathrm{PM}_{10}$ concentration exceeded $1 \mathrm{mg} / \mathrm{m}^{3}$. The second event (E2) was a holiday weekend and the third event (E3) was a heavy rain period. 


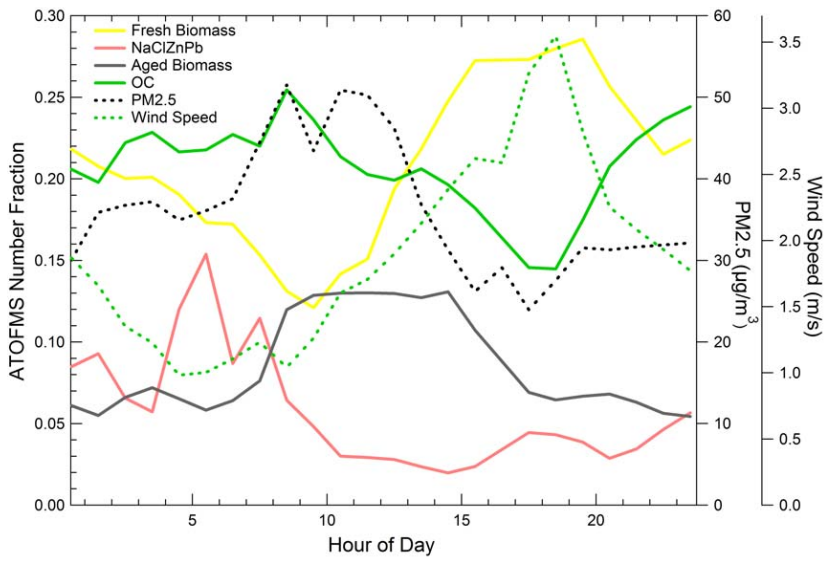

Fig. 7. Average diurnal trends of the ATOFMS number fractions. Industrial emissions $(\mathrm{NaClZnPb})$ were highest in the early morning. Contributions from $\mathrm{OC}$ and aged biomass particles peaked during the nighttime through the late morning hours after which the major fresh biomass fraction dominated in the afternoons when the wind speed increased, transporting particles from the location of the fires (south) directly to the sampling site at T0.

\subsubsection{Time series analysis of the full study}

Examining the study as a whole, major features in the overall submicron temporal trends (Fig. 6a) appear as sharp spikes of metal and nitrogen organic carbon (NOC) particles. Frequently the metal and NOC classes peaked in the morning, usually with relatively short spikes compared with the trends of the other particle classes (OC, biomass, etc.). When the number fractions of these particles peaked, the metal and NOC types represented up to 35 and $47 \%$ of the total number of submicron particle types. These sharp time features suggest that the sources of these particles are close to the T0 site. The total $\mathrm{PM}_{2.5}$ mass concentrations during these early morning periods were typically around $50 \mu \mathrm{g} / \mathrm{m}^{3}$ at the La Villa RAMA site which was the closest site to T0 making $\mathrm{PM}_{2.5}$ mass concentration measurements. The weekend event (E2) showed almost non-existent contributions from the metal and NOC types, indicating these particles were produced by industrial sources. After the rain event (E3), the fractional contribution from the biomass/biofuel burning decreased while the number fractions of the OC, NOC, and metal particles increased. This is not surprising as the fires in the area were greatly reduced during this rainy period (24-26 March). As expected, local sources (i.e. NOC and metal particles) dominated after the scavenging of the regional aerosols by the storms. Interestingly, the contributions from fresh biomass particles became almost negligible, while some aged biomass particles were still detected, suggesting these were regional biomass fires being transported to the sampling site. Overall, for the period of 24-26 March, the submicron aged OC and fresh and aged biomass parti- cle classes exhibited a relatively strong diurnal pattern which will be examined further in Sect. 3.4.2.

Figure $6 \mathrm{~b}$ shows the temporal profiles of the major supermicron particle types. There was one particularly large dust event caused by strong winds on 16 March 2006 beginning at 16:00 CST (E1) during which the measured $\mathrm{PM}_{10}$ exceeded $1 \mathrm{mg} / \mathrm{m}^{3}$ at the San Agustin and Xalostoc RAMA sites (near the dry lake bed Texcoco, SAG and XAL in Fig. 1) and almost $700 \mu \mathrm{g} / \mathrm{m}^{3}$ at the La Villa RAMA site closest to T0. The wind blew from these sites towards the west in the direction of T0. Our results show that the $\mathrm{Na} / \mathrm{K}$ and $\mathrm{Al} / \mathrm{Si}$ particle types dominated the chemical composition for this time period, thus indicating that the dry lake bed and fugitive dust sources nearby were major contributors to these particle types. This is consistent with the observations of Chow et al. (2002a, b), who found concentrations of $\mathrm{Al}, \mathrm{Si}, \mathrm{K}$, and $\mathrm{Na}$ to be highest around the SAG and XAL sites compared to other sites around the city.

\subsubsection{Average diurnal trends}

The average diurnal profile for four major submicron particle types (i.e. biomass, fresh biomass, $\mathrm{NaClZnPb}$ (industry), and $\mathrm{OC}$ ) are shown in Fig. 7. This figure shows how the relative abundances of the different particle types observed during MILAGRO were strongly correlated with meteorological patterns. In the early morning, starting at 3:30 a.m., when the wind speeds were low and coming mostly from the north, the fractional contribution of the $\mathrm{NaClZnPb}$ particle type peaked. Between 7-11 a.m., aged OC and biomass particles were the most abundant particle types. At about 11 a.m., the wind speed increased when the wind direction shifted and started coming from the south. When this shift occurred, contributions to the submicron fraction from the particle types derived from the North $(\mathrm{NaClZnPb})$ as well as the aged biomass and OC particle types decreased. Correlated with the shift in wind direction was an increase in the most abundant fresh biomass particle particles which were rapidly transported to the site from the south. These biomass particles most likely originated from agricultural fires in the foothills south of T0, as well as fires in the pine forests to the southeast occurred many afternoons as indicated by MODIS hot spots (Yokelson et al., 2007). It is important to note that smaller fires that were shorter in duration such as the local brush fires were often missed by MODIS satellite passes and thus hot spot data can often under-count the contributions from biomass/biofuel burning (Fast et al., 2007; Yokelson et al., 2007).

The number fraction of total biomass/biofuel particles (fresh + aged) varied from $7 \%$ to $76 \%$ during the study, with the highest fractions being detected in the late afternoons when the winds were coming from the south. During these afternoon time periods, the fresh biomass particle volume was centered about $300 \mathrm{~nm}$, indicating a relatively low contribution from secondary species. In contrast, aged biomass 
burning particles peaked in the early to mid-mornings and had extensive amounts of organic and inorganic secondary species associated with them. CFA back trajectory analysis shows that the fresh biomass particles peaked after the flow switched in the late morning 10:30-11:00 and began to come directly from the south. Relatively rapid transport brought fresh biomass particles in about 2-3 h from the locations of the fires directly to the site. This aspect will be discussed further in the following section using back trajectory and CFA analysis.

EC particles showed a bimodal diurnal temporal profile with the largest peak occurring at 7:30 a.m. and a second one occurring at 11:30 a.m. As shown in Fig. 8, the EC particles sampled during the early morning peak had smaller aerodynamic diameters (peaked at the smallest sizes detected by ATOFMS) than those sampled during the later peak (number distribution mode $=0.38 \mu \mathrm{m}$ ). Figure 8 shows that the EC particles later in the day had larger contributions from $\mathrm{NO}_{3}^{-}$, $\mathrm{NH}_{4}^{+}, \mathrm{C}_{3} \mathrm{H}_{3} \mathrm{O}^{+}$, and $\mathrm{K}^{+}$. With the exception of $\mathrm{K}^{+}$, these markers are indicative of secondary photochemical processing. Early morning EC particles had more intensity from ${ }^{12 n} \mathrm{C}_{\mathrm{n}}^{-}$clusters and sulfate in the negative ions as well as more intense $\mathrm{Na}^{+}$and $\mathrm{Ca}^{+}$ion peaks in the positive ion mass spectrum. These primary peaks suggest the EC in the mornings was coming from industry $\left(\mathrm{Na}^{+}\right)$and traffic $\left(\mathrm{Ca}^{+}\right)$. Based on these observations, it can be concluded that the early morning peak of EC is comprised of more freshly emitted vehicle particles. Later in the morning, the EC particles became more aged with the availability of more atmospheric oxidants. Finally, the EC particles sampled later in the day had more $\mathrm{K}^{+}$ signal indicating that biomass/biofuel burning was the main source producing these late afternoon EC (soot) particles.

\subsection{Back trajectory analysis}

A Concentration Field Analysis (Seibert, 1994) was carried out using back-trajectories from the FLEXPART model (Stohl et al., 2005; Fast et al., 2006). To accomplish this, 100 stochastic particles are released from T0 every $2 \mathrm{~h}$ and tracked for 3 days. All the positions of the particles every hour are summed into a gridded field indicating the source region of the air mass at each release time. These gridded fields, called Residence Time Analyses, are then multiplied by the ATOFMS normalized particle counts at the release site and summed over the entire campaign. Potential source regions are highlighted by normalizing with the sum of the unscaled residence time analysis. The method was used to analyze data from the MCMA-2003 field campaign (de Foy et al., 2007). Analysis of CO data showed that the method was able to correctly identify urban emissions and analysis of $\mathrm{SO}_{2}$ data identified possible impacts of the Tula industrial complex. This analysis was performed for each of the fifteen particle types seen during MCMA-2006; the results of this analysis are shown in Figs. 9-11. For particle types with

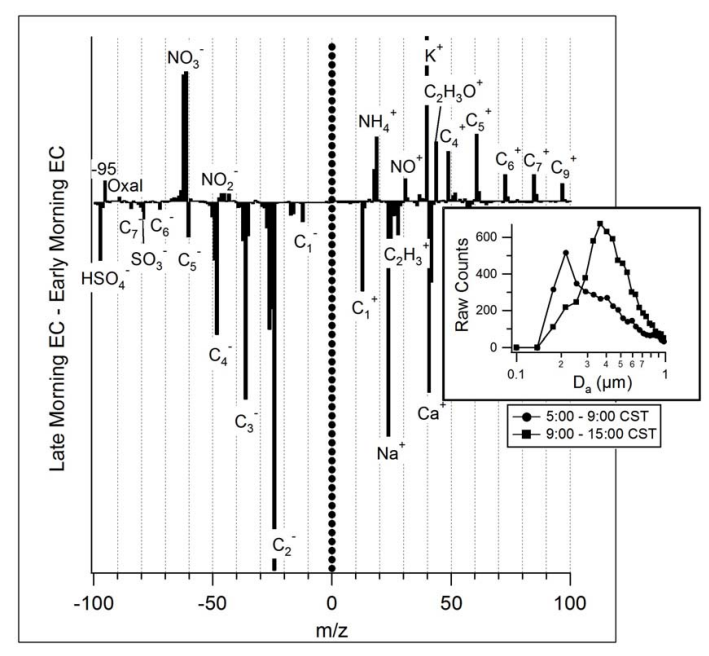

Fig. 8. A subtraction spectrum for EC particles peaking late in the morning/early afternoon ( 9 a.m. -3 p.m.) minus particles peaking early in the morning (5-9 a.m.). This shows that early morning EC particles have less contribution from markers of secondary photochemistry and more markers from freshly emitted EC (sulfate, $\mathrm{Na}^{+}$, and $\left.\mathrm{Ca}^{+}\right)$. Furthermore, the increase in $\mathrm{K}^{+}$later in the day suggests a contribution from biomass burning as the major EC source.

only a few sharp peaks, a single back trajectory corresponding the time of highest concentration is shown.

The wind fields for the trajectories were simulated using the Weather Research and Forecast model (WRF [Skamarock et al., 2005]). Three domains were used with $50 \times 40,64 \times 55$ and $61 \times 61$ cells at a horizontal resolution of 36,12 and $3 \mathrm{~km}$ respectively. 27 levels were used in the vertical. High resolution remote sensing data from the MODIS satellite sensors were used to improve the definition of the land surface in the model (de Foy et al., 2006).

\subsubsection{Spatial distribution of industrial emissions}

The T0 site is located in the heart of the industrial sector of the MCMA. As a result, local industrial emissions are expected to represent a large fraction of the particles detected at the T0 site. Typically, local point sources emit pollutants over short timescales. Such pollutant spikes were discussed in Sect. 3.4.1 for the metal and NOC particle types, where it was suggested these particle types are most likely from local industry. For the NOC type, this is verified by looking at the FLEXPART back trajectory shown in Fig. 9 for the largest NOC spike occurring at 9 a.m. on 15 March 2006. This figure indicates that flow was stagnant during the periods of peak NOC emissions, suggesting these particles came from a local source. Similar flow conditions were observed during other periods of the study when the NOC particles were most abundant. 


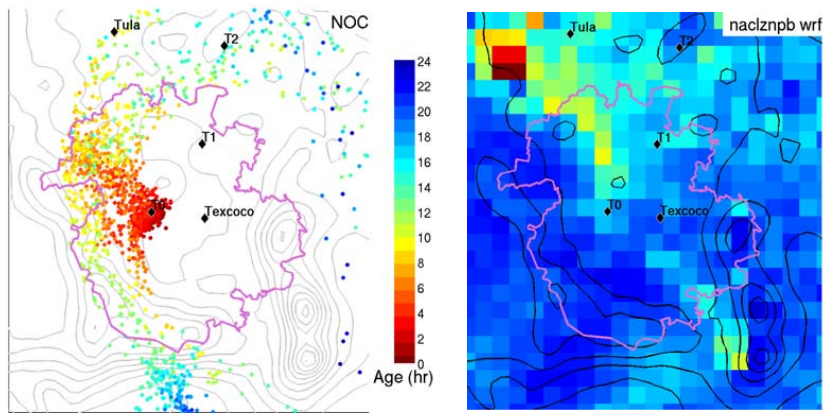

Fig. 9. Spatial distributions of industrial emissions in Mexico City. (a) Particle back-trajectories for a release on 15 March, 08:00 09:00 CST, for a representative nitrogen organic carbon (NOC) peak in the time series. Particle positions are plotted every hour and color indicates age. (b) Concentration field analysis for $\mathrm{PbZn}$ particles. High non-dimensional number (red) indicates possible source region, low numbers (blue) indicate areas with low or zero emissions.

As shown in Fig. 6, the NaClPbZn class was detected from midnight to about 10:00 (CST). The concentration field analysis in Fig. 9 indicates possible source regions north of $\mathrm{T} 0$ for the $\mathrm{NaClZnPb}$ particle type. Concentrations of $\mathrm{Pb}$ and $\mathrm{Zn}$ in northern Mexico City have been historically high compared to other regions of Mexico City (Chow et al., 2002). There is evidence for transport of $\mathrm{Na}$ and $\mathrm{Zn}$ particles from the northern parts of the city, as Johnson et al. (2006) have shown. At the same site, Salcedo et al. (2006) noticed sharp mass concentration spikes of particulate $\mathrm{Cl}$ in the early morning hours. In this study, we observe early morning spikes of chloride as well, and show that it is internally mixed with $\mathrm{Pb}$, $\mathrm{Zn}$, Na. Johnson et al. (2006) attributed the $\mathrm{Na}$ and $\mathrm{Zn}$ to an industrial source in their factor analysis, and Salcedo et al. hypothesized that most of the $\mathrm{Cl}$ was present as $\mathrm{NH}_{4} \mathrm{Cl}$. The results obtained herein show that the $\mathrm{Na}, \mathrm{Cl}$, and $\mathrm{Zn}$ are in the same particles and likely produced by local industry in the north (Fig. 5). The $\mathrm{Cl}$ is most likely in the form of $\mathrm{NaCl}$, $\mathrm{KCl}, \mathrm{ZnCl}_{2}$, and/or $\mathrm{PbCl}_{2}$ based on the measured single particle chemistry, instead of $\mathrm{NH}_{4} \mathrm{Cl}$ as suggested previously. For all of the metal chloride species, displacement of $\mathrm{Cl}$ by nitrate explains the strong association of the metal particle classes with nitrate in the late morning periods.

\subsubsection{Spatial trends of carbonaceous particle types}

Both primary and secondary components of carbonaceous particles in Mexico City are produced by a variety of urban and regional sources. Figure 10 shows the concentration field analysis for the main carbonaceous particle types. As shown in Fig. 10a, OC particles types were distributed across the basin and formed under more stagnant conditions. More stagnant conditions are conducive to the formation of more oxidized/aged species within the basin, such as those asso-
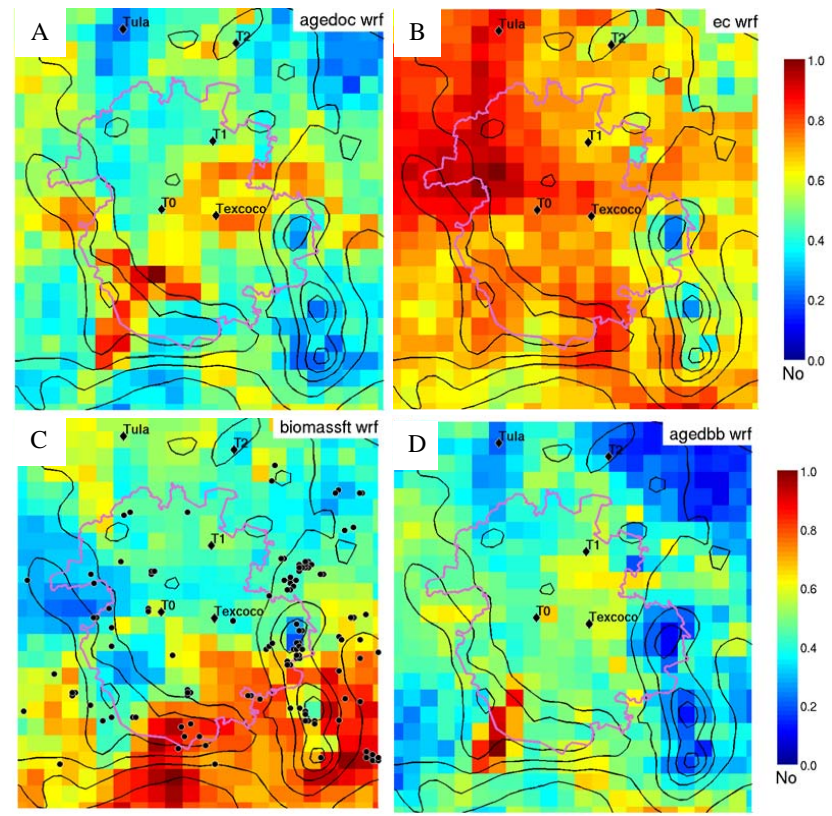

Fig. 10. Spatial distributions of major submicron carbonaceous types in Mexico City. (a) CFA of aged organic carbon particles, showing they were spatially distributed across the basin. (b) Concentration field analysis for EC particles, showing they came mainly from the northwest and south. (c) CFA for fresh biomass particles showing these came mainly from the south when winds picked up in the afternoons. Transport in the afternoons took approximately $2 \mathrm{~h}$ to get from the regions of the fires to the T0 sampling site. Black dots show locations of MODIS hot spots during this week of the study. (d) Aged BB, showing a similar pattern to aged OC types, occur when winds were more stagnant and originated in the southwest. Typically, when winds came from this direction it took longer times (1-3 days) for the particles to reach T0. High nondimensional number (red) indicates possible source regions, low numbers (blue) indicate areas with low or zero emissions.

ciated with the OC type, which can form uniformly across the basin as opposed to directly from one point source. As described, the OC particle spectra showed the particles had undergone aging in the late mornings, becoming associated with significant amounts of nitrate, ammonium, and sulfate. The occurrence of these particle types is consistent with the previous MCMA-2003 campaign which showed significant contributions from oxidized organic species which were assigned to secondary organic aerosols (Salcedo et al., 2006; Volkamer et al., 2006). Figure 10b shows the EC particle type which also shows a broad spatial pattern but significant contributions from the northwest. Because EC represents a freshly emitted particle type and also because concentrations are highest when winds are weak and variable, the Concentration Field Analysis does not indicate a preferred source region. EC particles coming from the north most likely came 
from industrial operations. EC particles came from many directions, indicating they were produced by several sources including heavy duty vehicles, industry, and biomass burning emissions.

As shown in Fig. 10c, fresh biomass particles show a strong correlation with flow through the gap from the mountains to the south and southeast of the city - a region where large fires and smaller brush fires occurred (Fast et al., 2007). This type of flow usually began in the late morning (11 a.m., see Fig. 7) when the fresh biomass particles began to increase; this time period is also associated with vertical advection and basin venting (de Foy et al., 2005, 2006; Fast et al., 2007). When the winds shifted so that they were coming from the south, lower contributions came from other types including more aged particle types as well as those from the northern city region (i.e. OC, industrial sources) which resulted in overall lower $\mathrm{PM}_{2.5}$ mass concentrations. The majority of the PM during the afternoons came from relatively fresh biomass burning particles transported from the south during most periods of the study with the exception of the last three days (24-27 March) when a period of rain reduced the number of fires. The increased source strength for the biomass particles near the hillsides of the basin was associated with numerous small fires on these hills used to clear fields for the upcoming crop season. MODIS hotspots produced by the University of Maryland (UMD) Web Fire Mapper (http://maps.geog.umd.edu) are shown in Fig. 10c as black dots (Justice et al., 2002). It is important to note that the smaller brush fires were often not captured in MODIS satellite images (Fast et al., 2007). Aged biomass types originated in the southwest and appeared during the night and early morning hours when the flow was more stagnant. Based on the back trajectory analysis, particles from the southwest region were transported more slowly (1-3 days) to $\mathrm{T} 0$ and thus had more time to undergo aging. This was evident in the single particle mass spectra which showed more nitrate, ammonium, and oxidized organic species on the biomass types that came from this region of the city. In contrast, the fresher biomass types shown in Fig. 10b were transported by higher winds quickly to the site $(2-3 \mathrm{~h})$ from the south and southeast showed far less aging.

\subsubsection{Spatial trends in coarse mode particle types}

The concentration field analysis for the coarse (supermicron) mode particle types is shown in Fig. 11. AlSi, Ca and Fe dust all had similar spatial footprints where the highest concentration events correlated well with flow from the northwest near the Tula region. For the Ca type, this would be consistent with the fact that the cement plants in that region emit dust with high concentrations of $\mathrm{Ca}$ (Vega et al., 2001). The Fe particle type had slightly more influence from the northwest than did the AlSi or Ca types. The NaK particle type was significantly different from any other coarse mode particle type, showing more contributions from the east to
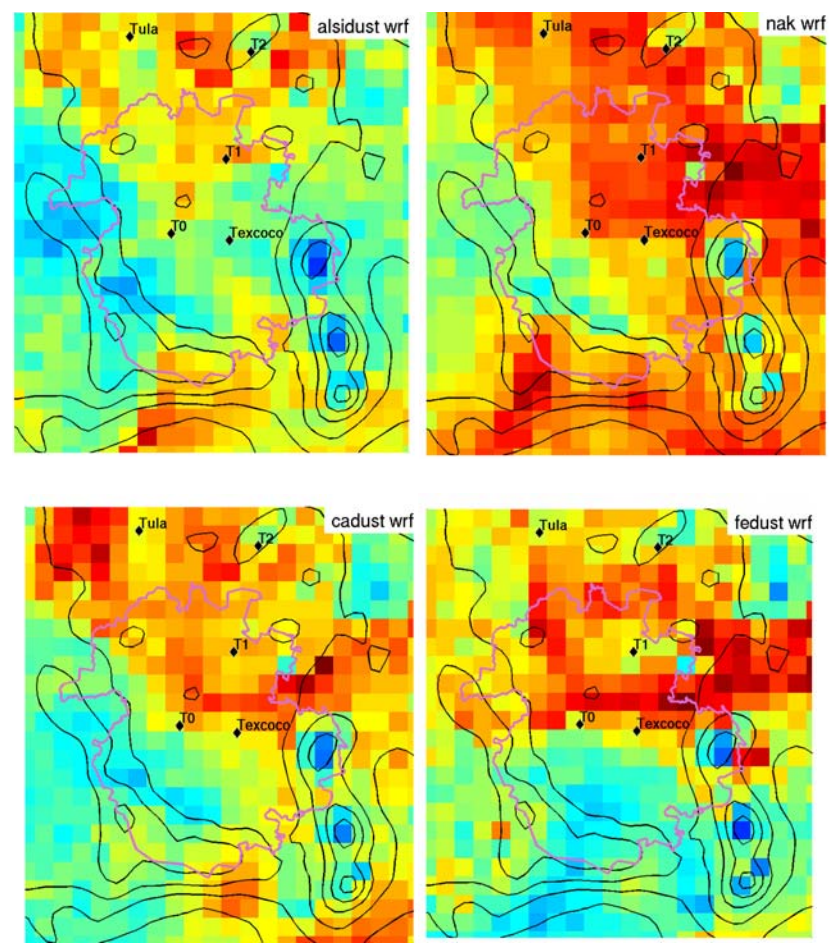

Fig. 11. Concentration field analysis for select coarse mode particle types. High non-dimensional number (red) indicates possible source regions, low numbers (blue) indicate areas with low or zero emissions. Texcoco is a dry lake bed expected to be a major source of coarse mode dust.

northeast. The dry lake bed Texcoco is located in the east, and has been historically correlated with large quantities of $\mathrm{Na}$ and $\mathrm{K}$ compared to the rest of Mexico City. The broad spatial pattern is consistent with the fact that the NaK type was produced by multiple sources. Based on the single particle signatures, some of the NaK type particles were mixed with soot and formed in the early morning hours. These particles were formed by combustion sources in the upper northwest region of the city.

3.6 Comparison with other measurements and previous studies

In this paper, we report biomass/biofuel burning number fractions in the submicron mode as being $40 \%$ when averaged over the full study and ranging from $7 \%$ to $76 \%$ of the submicron number fraction for the observed daily variations. The reported percentages for biomass contributions in this study, which are consistent with other published studies from 2006, suggest that biomass/biofuel burning makes a significant contribution to the Mexico City aerosol. Yokelson et al. (2007) estimated that fires contributed $20-80 \%$ of the fine particle mass $\left(\mathrm{PM}_{2.5}\right)$ in the Mexico City area outflow during 
MILAGRO in 2006. Stone et al. (2007) reported that biomass burning accounted for 5-30\% (12 h averages) of the $\mathrm{PM}_{2.5}$ mass concentrations. A recent paper by DeCarlo et al. (2007) describes airborne measurements of the non-refractory components in $\mathrm{PM}_{1}$ above Mexico City in which secondary organic aerosols and biomass burning aerosols dominate the organic aerosol (DeCarlo et al. 2007). The 2006 MILAGRO study contrasts an earlier study, MCMA-2003, where for the majority of the study, vehicles and secondary species were reported to be the most abundant sources of $\mathrm{PM}_{2.5}$ (Salcedo et al., 2006; Volkamer et al., 2006). Johnson et al. (2006) used PIXE analysis of single particles in 2003 and also noted that biomass burning made significant contributions to the refractory components of the aerosol during the later part of the study (Johnson et al., 2006). There are a number of possible reasons for the smaller observed influence of fires in 2003 including differences in transport conditions, meteorology, and/or the numbers of fires in the local region. MODIS hot spot data were used to estimate that major fires in the region did not impact the region until the later part of the study in 2003. However, as mentioned, MODIS hot spot do not detect shorter duration smaller fires and thus tend to serve as a lower limit for the impact of biomass/biofuel burning in a particular region. The exact contributions from biomass/biofuel burning in 2003 to the non-refractory organic aerosol are still being investigated using factor analysis which subdivides the organic aerosol fraction detected with the AMS into several different factors, including a recently reported wood smoke organic factor (Alfarra et al., 2007; Lanz et al., 2007; Molina et al., 2007).

It is important to recognize that many sources of biomass/biofuel particles exist in the Mexico City region: 1) wood smoke from regional fires, 2) cooking, 3) incineration, 4) agricultural fires, and 5) refuse burning. Thus, it is not surprising that biomass/biofuel particles represent such a sizeable fraction of the aerosol. In the current analysis of ATOFMS data, many of these sources are combined into the general fresh and aged biomass types, as well as the Na$\mathrm{ClZnPb}$ particle types. In a future paper, the different mass spectral fingerprints will be examined in the different size ranges and compared with other measurements, models, and back trajectory analysis to gain further insights into the major biomass/biofuel sources contributing to the particulate matter in Mexico City.

In addition to finding significant contributions from biomass/biofuel burning, the single particle mass spectrometry ATOFMS results from this study provide new insights into sources for a number of previously observed particle components including $\mathrm{Zn}$ and chloride (Johnson et al., 2006). In this study, high morning chloride concentrations were shown to be emitted in the form of mixed $\mathrm{Zn}, \mathrm{Pb}$, and $\mathrm{Cl}$ particles produced by industrial sources, possibly incineration processes, in the northern region of the city. Previous speculation based on bulk chloride mass concentrations hypothesized the chloride was due to $\mathrm{NH}_{4} \mathrm{Cl}$ (Salcedo et al.,
2006). Salcedo et al. (2006) attributed submicron inorganic components including $\mathrm{Al}, \mathrm{Si}, \mathrm{Ca}, \mathrm{Fe}, \mathrm{Ti}, \mathrm{K}$, and $\mathrm{Mg}$ to soil in 2003, however this study shows significant inorganic salts, transition metals, and dust particles were also produced in the submicron size range by industrial processes. Single particle mass spectral data also provide insights into how heterogeneous processes on inorganic salt particle types, both from the dry lake bed as well as industrial sources, convert high chloride concentrations in the early morning hours to nitrate later in the morning, showing how dust particles affect $\mathrm{NO}_{\mathrm{y}}$ budget in Mexico City.

\section{Conclusions}

ATOFMS observations during MCMA-2006 provide chemical mixing state measurements with high temporal and size resolution. Industrial operations produced a nitrogencontaining organic (NOC) particle type as well as $\mathrm{Pb}$ particles internally mixed with $\mathrm{Zn}$ and $\mathrm{Cl}$. These industrial particle types peaked in the morning hours and were likely produced in the northern region of the city. Given the spatial and temporal characteristics of particles with the $\mathrm{PbZnCl}$ mixing state, these particles are the dominant source of early morning particulate phase chloride. Furthermore, these same metal particles are likely associated with the source of high $\mathrm{Pb}$ and $\mathrm{Zn}$ concentrations in the north described in previous investigations. These particles and their chemistry are the subject of another paper (Moffet et al., 2008).

The most abundant submicron particle types detected in the MCMA included biomass/biofuel, industrial, and OC particle types, whereas inorganic salt and dust particle types dominated the coarse (super-micron) mode. When the wind speeds increased and came from the south during the afternoons, the biomass/biofuel particles represented up to $76 \%$ of the number fraction of submicron particles. Knowing which particle types represent the largest number fractions of the "seed" aerosol is extremely important to understanding the major primary sources impacting the partitioning of secondary species (i.e. SOA) in Mexico City.

The mixing of the different major particle types with secondary species was analyzed using a peak searching method. Organic carbon was found to be on almost 50\% of the coarse mode dust particles, while $45 \%$ of the biomass and $37 \%$ of the vanadium particles were associated with the oxalate ion. It was determined that $58 \%$ of the EC particles and $73 \%$ of the ECOC particles contained sulfate. This demonstrates that these freshly emitted carbonaceous particle types contained both primary and secondary inorganic components.

A time series analysis of the different particle types provides insight into the potential sources and transformations occurring on the particles. Distinct diurnal variations for the $\mathrm{OC}$ and biomass particle types were observed with the aged biomass and OC particles present as the most abundant types in the early morning, then after 11:00 CST, fresh biomass 
particles began to increase, becoming the most abundant submicron particle class by number fraction in the late afternoons. After 18:00 CST, OC particles started to increase in concentration while the fresh biomass particles decreased. The observed diurnal variations show the importance of meteorology in controlling the major sources making contributions to ambient PM in Mexico City. These time series for the different particle types serve as a "clock" of the sources, aging, and transport characteristics of the aerosol in the heart of the MCMA, thus providing a timescale on which measurements can be compared with models. To this end, these temporal profiles provided by the ATOFMS were used, together with meteorological modeling, to provide source regions for the major particle types.

CFA analysis combined with the ATOFMS data from this study show how submicron inorganic salt, soot, and metal types from northern industrial sources can make substantial contributions to the submicron number fraction during the early morning hours. The aged version of most particles types occurs from 10 a.m. to 12 p.m. when photochemical activity was highest. A strong contrast in sources and overall PM concentrations is observed when the wind direction shifts and increases in speed from northerly to southerly in the late mornings. Interestingly, when the winds were weak and particles were coming from the north and/or across the basin, they tended to be more aged and the PM mass concentrations were at their highest. When the wind speeds increased and the air parcels came from the south, biomass particles appeared with less signs of aging and overall lower $\mathrm{PM}_{2.5}$ mass concentrations were generally observed. Given the wind speeds and distance from $\mathrm{T} 0$ to the locations of the fires, it is calculated that the biomass burning particles were transported to the site in $2-3 \mathrm{~h}$ during the afternoons. Given the high density urban area south of T0, it is somewhat surprising how strongly biomass burning dominated the overall aerosol (up to $76 \%$ ) when the winds became southerly. In future analyses, direct comparisons will be made between the ATOFMS and other measurements (i.e. AMS, optical measurements, emissions inventories, radiative transfer and chemical transport models) to obtain a better understanding of how the sources and aging processes impacted the overall properties of aerosols. It is especially essential to fold these observations into particle-resolved models in order to gain a better understanding of important sources and processes affecting the physical and chemical properties of the Mexico City aerosol (Fast et al., 2006).

Acknowledgements. This field campaign was the collaborative effort of a large number of participants with the support of multi-national agencies. The authors would like to thank Gustavo Sosa, Philip Sheehy, Rainer Volkamer, Jose Luis Jimenez, and Ken Docherty for their assistance and guidance during the MCMA-2006 field study. Rene Sanchez overcame the location problems of our digitizers. Robert Osborne and Don Collins helped organize and consolidate the shipment of equipment into Mexico. Tania Perez and Ricardo Cepeda provided much needed and timely logistical support. Rafael Ramos graciously provided gas phase and PM data from the RAMA monitoring network. We thank NSF for funding under ATM-0511803 and ATM-0528227. We thank Bob Yokelson for many useful discussions and his edits of the manuscript.

Edited by: S. Madronich

\section{References}

Aiken, A. C., DeCarlo, P. F., and Jimenez, J. L.: Elemental analysis of organic species with electron ionization high-resolution mass spectrometry, Anal. Chem., 79, 8350-8358, 2007.

Aldape, F., Flores, J., Diaz, R. V., and Crumpton, D.: Upgrading of the PIXE system at ININ (Mexico) and report on elemental composition of atmospheric aerosols from 1990 in the ZMCM, NIM-B, 109, 459-464, 1996.

Aldape, F., Flores, J., Garcia, R., and Nelson, J. W.: PIXE analysis of atmospheric aerosols from a simultaneous three site sampling during the autumn of 1993 in Mexico city, Nuclear Instruments and Methods in Physics Research Section B - Beam Interactions with Materials and Atoms, 109, 502-505, 1996.

Alfarra, M. R. Prevot, A. S. H., Szidat, S.,Sandradewi, J., Weimer, S., Lanz, V. A., Schreiber, D., Mohr, M., and Baltensperger, U.: Identification of the mass spectral signature of organic aerosols from wood burning emissions, Environ. Sci. Technol., 41, 57705777, 2007.

Allen, J. O., Fergenson, D. P., Gard, E. E., Hughes, L. S., Morrical, B. D., Kleeman, M. J., Gross, D. S., Gaelli, M. E., Prather, K. A., and Cass, G. R.: Particle detection efficiencies of aerosol time of flight mass spectrometers under ambient sampling conditions, Environ. Sci. Technol., 34, 211-217, 2000.

Angelino, S., Suess, D. T., and Prather, K. A.: Formation of aerosol particles from reactions of secondary and tertiary alkylamines: Characterization by aerosol time-of-flight mass spectrometry, Environ. Sci. Technol., 35, 3130-3138, 2001.

Arimoto, R., Kim, Y. J., Kim, Y. P., Quinn, P. K., Bates, T. S., Anderson, T. L., Gong, S., Uno, I., Chin, M., Huebert, B. J., Clarke, A. D., Shinozuka, Y., Weber, R. J., Anderson, J. R., Guazzotti, S. A., Sullivan, R. C., Sodeman, D. A., Prather, K. A., and Sokolik, I. N.: Characterization of Asian Dust during ACE-Asia, Global Planet. Change, 52(1-4), 23-56, 2006.

Baumgardner, D., Raga, G. B., and Muhlia, A.: Evidence for the formation of $\mathrm{CCN}$ by photochemical processes in Mexico city, Atmos. Environ., 38, 357-367, 2004.

Beddows, D. C. S., Donovan, R. J., Harrison, R. M., Heal, M. R., Kinnersley, R. P., King, M. D., Nicholson, D. H., and Thompson, K. C.: Correlations in the chemical composition of rural background atmospheric aerosol in the uk determined in real time using time-of-flight mass spectrometry, J. Environ. Monitor., 6, 124-133, 2004.

Blando, J. D. and Turpin, B. J.: Secondary organic aerosol formation in cloud and fog droplets: A literature evaluation of plausibility, Atmos. Environ., 34, 1623-1632, 2000.

Cahill, T. A., Morales, R., and Miranda, J.: Comparative aerosol studies of Pacific rim cities - santiago, chile (1987); Mexico city, Mexico (1987-1990); and Los Angeles, USA (1973 and 1987), Atmos. Environ., 30, 747-749, 1996.

Chebbi, A. and Carlier, P.: Carboxylic acids in the troposphere, occurrence, sources, and sinks: A review, Atmos. Environ., 30, 
4233-4249, 1996.

Chow, J. C., Watson, J. G., Edgerton, S. A., and Vega, E.: Chemical composition of $\mathrm{PM}_{2} .5$ and $\mathrm{PM}_{1} 0$ in Mexico city during winter 1997, Sci. Total Environ., 287, 177-201, 2002.

Chow, J. C., Watson, J. G., Edgerton, S. A., Vega, E., and Ortiz, E.: Spatial differences in outdoor $\mathrm{PM}_{1} 0$ mass and aerosol composition in Mexico city, J. Air Waste Manage., 52, 423-434, 2002.

de Foy, B., Caetano, E., Magana, V., Zitacuaro, A., Cardenas, B., Retama, A., Ramos, R., Molina, L. T., and Molina, M. J.: Mexico city basin wind circulation during the MCMA-2003 field campaign, Atmos. Chem. Phys., 5, 2267-2288, 2005,

http://www.atmos-chem-phys.net/5/2267/2005/.

de Foy, B., Caetano, E., Magaña, V., Zitácuaro, A., Cárdenas, B., Retama, A., Ramos, R., Molina, L. T., and Molina, M. J.: Mexico City basin wind circulation during the MCMA-2003 field campaign, Atmos. Chem. Phys., 5, 2267-2288, 2005, http://www.atmos-chem-phys.net/5/2267/2005/.

de Foy, B., Molina, L. T., and Molina, M. J.: Satellite-derived land surface parameters for mesoscale modeling of the Mexico City basin, Atmos. Chem. Phys., 6, 1315-1330, 2006,

http://www.atmos-chem-phys.net/6/1315/2006/.

de Foy, B., Varela, J. R., Molina, L. T., and Molina, M. J.: Rapid ventilation of the Mexico City basin and regional fate of the urban plume, Atmos. Chem. Phys., 6, 2321-2335, 2006,

http://www.atmos-chem-phys.net/6/2321/2006/.

de Foy, B., Lei, W., Zavala, M., Volkamer, R., Samuelsson, J., Mellqvist, J., Galle, B., Martnez, A.-P., Grutter, M., Retama, A., and Molina, L. T.: Modelling constraints on the emission inventory and on vertical dispersion for $\mathrm{CO}$ and $\mathrm{SO} 2$ in the Mexico City Metropolitan Area using Solar FTIR and zenith sky UV spectroscopy, Atmos. Chem. Phys., 7, 781-801, 2007, http://www.atmos-chem-phys.net/7/781/2007/.

DeCarlo, P. F., Dunlea, E. J., Kimmel, J. R., Aiken, A. C., Sueper, D., Crounse, J., Wennberg, P. O., Emmons, L., Shinozuka, Y., Clarke, A., Zhou, J., Tomlinson, J. D., Collins, R., Knapp, D., Weinheimer, A. J., Montzka, D. D., Campos, T., and Jimenez, J. L.: Fast airborne aerosol size and chemistry measurements with the high resolution aerosol mass spectrometer during the MILAGRO campaign, Atmos. Chem. Phys. Discuss., 7, 18269 18317, 2007.

Dunn, M. J., Jiménez, J. L., Baumgardner, D., Castro, T., McMurry, P. H., and Smith, J. N. : Measurements of Mexico city nanoparticle size distributions: Observations of new particle formation and growth, Geophys. Res. Let., 31, L10102, doi:10.1029/2004GL019483, 2004.

Ervens, B., Feingold, G., Frost, G. J., and Kreidenweis, S. M.: A modeling study of aqueous production of dicarboxylic acids: 1 . Chemical pathways and speciated organic mass production, J. Geophys. Res., 109, D15205, doi:10.1029/2003JD004387, 2004.

Falkovich, A. H., Graber, E. R., Schkolnik, G., Rudich, Y., Maenhaut, W., and Artaxo, P.: Low molecular weight organic acids in aerosol particles from Rondnia, Brazil, during the biomassburning, transition and wet periods, Atmos. Chem. Phys., 5, 781797, 2005,

http://www.atmos-chem-phys.net/5/781/2005/.

Fast, J. D. and Easter, R.: A lagrangian particle dispersion model compatible with WRF, in: 7th WRF User's Workshop, Boulder, CO, 2006.

Fast, J. D., Gustafson, W. I., Easter, R. C., Zaveri, R. A.,
Barnard,J. C., Chapman, E. G., Grell, G. A., and Peckham, S. E.: Evolution of ozone, particulates, and aerosol direct radiative forcing in the vicinity of Houston using a fully coupled meteorology-chemistry-aerosol model, J. Geophys. Res., 111, D21305, doi:10.1029/2005JD006721, 2006.

Fast, J. D., de Foy, B., Acevedo Rosas, F., Caetano, E., Carmichael, G., Emmons, L., McKenna, D., Mena, M., Skamarock, W., Tie, X., Coulter, R. L., Barnard, J. C., Wiedinmyer, C., and Madronich, S.: A meteorological overview of the MILAGRO field campaigns, Atmos. Chem. Phys., 7, 2233-2257, 2007, http://www.atmos-chem-phys.net/7/2233/2007/.

Faust, B. C.: Photochemistry of clouds, fogs, and aerosols, Environ. Sci. Technol., 28, A217-a222, 1994.

Flores, J., Aldape, F., Diaz, R. V., Hernandez-Mendez, B., and Garcia, R.: PIXE analysis of airborne particulate matter from Xalostoc, Mexico: Winter to summer comparison, Nuclear Instruments and Methods in Physics Research Section B - Beam Interactions with Materials and Atoms, 150, 445-449, 1999.

Gard, E., Mayer, J. E., Morrical, B. D., Dienes, T., Fergenson, D. P., and Prather, K. A.: Real-time analysis of individual atmospheric aerosol particles: Design and performance of a portable ATOFMS, Anal. Chem., 69, 4083-4091, 1997.

Gard, E. E., Kleeman, M. J., Gross, D. S., Hughes, L. S., Allen, J. O., Morrical, B. D., Fergenson, D. P., Dienes, T., Galli, M. E., Johnson, R. J., Cass, G. R., and Prather, K. A.: Direct observation of heterogeneous chemistry in the atmosphere, Science, 279, 1184-1187, 1998.

Graedel, T. E. and Keene, W. C.: Tropospheric budget of reactive chlorine, Global Biogeochem. Cys., 9, 47-77, 1995.

Guazzotti, S. A., Suess, D. T., Coffee, K. R., Quinn, P. K., Bates, T. S., Wisthaler, A., Hansel, A., Ball, W. P., Dickerson, R. R., Neususs, C., Crutzen, P. J., and Prather, K. A.: Characterization of carbonaceous aerosols outflow from India and Arabia: Biomass/biofuel burning and fossil fuel combustion, J. Geophys. Res., 108(D15), 4485, doi:10.1029/2002JD003277, 2003.

Hedberg, E. and Johansson, C.: Is levoglucosan a suitable quantitative tracer for wood burning? Comparison with receptor modeling on trace elements in lycksele, sweden, J. Air Waste Manage., 56, 1669-1678, 2006.

Hu, C. W., Chao, M. R., Wu, K. Y., Chang-Chien, G. P., Lee, W. J., Chang, L. W., and Lee, W. S.: Characterization of multiple airborne particulate metals in the surroundings of a municipal waste incinerator in taiwan, Atmos. Environ., 37, 2845-2852, 2003.

Jiang, M., Marr, L. C., Dunlea, E. J., Herndon, S. C., Jayne, J. T., Kolb, C. E., Knighton, W. B., Rogers, T. M., Zavala, M., Molina, L. T., and Molina, M. J.: Vehicle fleet emissions of black carbon, polycyclic aromatic hydrocarbons, and other pollutants measured by a mobile laboratory in Mexico City, Atmos. Chem. Phys., 5, 3377-3387, 2005,

http://www.atmos-chem-phys.net/5/3377/2005/.

Jimenez, J. C., Raga, G. B., Baumgardner, D., Castro, T., Rosas, I., Baez, A., and Morton, O.: On the composition of airborne particles influenced by emissions of the volcano popocatepetl in Mexico, Natural Hazards, 31, 21-37, 2004.

Johnson, K. S., Zuberi, B., Molina, L. T., Molina, M. J., Iedema, M. J., Cowin, J. P., Gaspar, D. J., Wang, C., and Laskin, A.: Processing of soot in an urban environment: case study from the Mexico City Metropolitan Area, Atmos. Chem. Phys., 5, 3033- 
3043, 2005,

http://www.atmos-chem-phys.net/5/3033/2005/.

Johnson, K. S., de Foy, B., Zuberi, B., Molina, L. T., Molina, M. J., Xie, Y., Laskin, A., and Shutthanandan, V.: Aerosol composition and source apportionment in the Mexico City Metropolitan Area with PIXE/PESA/STIM and multivariate analysis, Atmos. Chem. Phys., 6, 4591-4600, 2006,

http://www.atmos-chem-phys.net/6/4591/2006/.

Justice, C. O., Giglio, L., Korontzi, S., Owens, J., Morisette, J. T., Roy, D., Descloitres, J., Alleaume, S., Petitcolin, F., and Kaufman, Y.: The modis fire products, Remote Sens. Environ., 83, 244-262, 2002.

Kanakidou, M., Seinfeld, J. H., Pandis, S. N., Barnes, I., Dentener, F. J., Facchini, M. C., Van Dingenen, R., Ervens, B., Nenes, A., Nielsen, C. J., Swietlicki, E., Putaud, J. P., Balkanski, Y., Fuzzi, S., Horth, J., Moortgat, G. K., Winterhalter, R., Myhre, C. E. L., Tsigaridis, K., Vignati, E., Stephanou, E. G., and Wilson, J.: Organic aerosol and global climate modelling: a review, Atmos. Chem. Phys., 5, 1053-1123, 2005,

http://www.atmos-chem-phys.net/5/1053/2005/.

Kawamura, K. and Kaplan, I. R.: Motor exhaust emissions as a primary source for dicarboxylic-acids in los-angeles ambient air, Environ. Sci. Technol., 21, 105-110, 1987.

Kawamura, K. and Ikushima, K.: Seasonal changes in the distribution of dicarboxylic acids in the urban atmosphere, Environ. Sci. Technol., 27, 2227-2235, 1993.

Krueger, B. J., Grassian, V. H., Cowin, J. P., and Laskin, A.: Heterogeneous chemistry of individual mineral dust particles from different dust source regions: The importance of particle mineralogy, Atmos. Environ., 38, 6253-6261, 2004.

Lanz, V. A., Alfarra, M. R., Baltensperger, U., Buchmann, B., Hueglin, C., and Prévôt, A. S. H.: Source apportionment of submicron organic aerosols at an urban site by factor analytical modelling of aerosol mass spectra, Atmos. Chem. Phys., 7, 15031522, 2007,

http://www.atmos-chem-phys.net/7/1503/2007/.

Laskin, A., Wietsma, T. W., Krueger, B. J., and Grassian, V. H.: Heterogeneous chemistry of individual mineral dust particles with nitric acid: A combined CCSEM/EDX, ESEM, and ICP-MS study, J. Geophys. Res., 110, D10208, doi:10.1029/2004JD005206, 2005.

Liu, D. Y., Wenzel, R. J., and Prather, K. A.: Aerosol timeof-flight mass spectrometry during the Atlanta Supersite experiment: 1. Measurements, J. Geophys. Res., 108(D7), 8426, doi:10.1029/2001JD001562, 2003.

Marr, L. C., Dzepina, K., Jimenez, J. L., Reisen, F., Bethel, H. L., Arey, J., Gaffney, J. S., Marley, N. A., Molina, L. T., and Molina, M. J.: Sources and transformations of particle-bound polycyclic aromatic hydrocarbons in Mexico City, Atmos. Chem. Phys., 6, 1733-1745, 2006, http://www.atmos-chem-phys.net/6/1733/2006/.

Mazzoleni, L. R., Zielinska, B., and Moosmuller, H.: Emissions of levoglucosan, methoxy phenols, and organic acids from prescribed burns, laboratory combustion of wildland fuels, and residential wood combustion, Environ. Sci. Technol., 41, 21152122, 2007.

Miranda, J., Morales, J. R., Cahill, T. A., Aldape, F., and Flores, J.: A study of elemental contents in atmospheric aerosols in Mexicocity, Atmosfera, 5, 95-108, 1992.
Miranda, J., Cahill, T. A., Morales, J. R., Aldape, F., Flores, J., and Diaz, R. V.: Determination of elemental concentrations in atmospheric aerosols in Mexico-city using proton-induced x-ray emission, proton elastic-scattering, and laser-absorption, Atmos. Environ., 28, 2299-2306, 1994.

Miranda, J., Lopez-Suarez, A., Paredes-Gutierrez, R., Gonzalez, S., de Lucio, O. G., Andrade, E., Morales, J. R., and AvilaSobarzo, M. J.: A study of atmospheric aerosols from five sites in Mexico city using PIXE, Nuclear Instruments and Methods in Physics Research Section B - Beam Interactions with Materials and Atoms, 137, 970-974, 1998.

Miranda, J., Barrera, V. A., Espinosa, A. A., Galindo, O. S., NunezOrosco A., Montesinos, R. C., Leal-Castro, A., and Meinguer, J.: PIXE analysis of atmospheric aerosols from three sites in Mexico city, Nuclear Instruments and Methods in Physics Research Section B - Beam Interactions with Materials and Atoms, 219-220, 157-160, 2004.

Moffet, R. C. and Prather, K. A.: Extending ATOFMS measurements to include refractive index and density, Anal. Chem., 77, 6535-6541, 2005.

Moffet, R. C., Desyaterik, Y., Hopkins, R. J., Tivanski, A. V., Gilles, M. K., Shutthanandan, V., Molina, L. T., Gonzalez, R. A., Johnson, K. S., Mugica, V., Molina, M. J., Laskin, A. L., and Prather, K. A.: Characterization of aerosols containing $\mathrm{Zn}, \mathrm{Pb}$, and $\mathrm{Cl}$ from an industrial region of Mexico city, Environ. Sci. Technol., in press, 2008.

Molina, L. T. and Molina, M. J.: Air quality in the mexico megacity: An integrated assessment, Boston, Kluwer Academic Publishers, 2002.

Molina, L. T., Kolb, C. E., de Foy, B., Lamb, B. K., Brune, W. H., Jimenez, J. L., Ramos-Villegas, R., Sarmiento, J., ParamoFigueroa, V. H., Cardenas, B., Gutierrez-Avedoy, V., and Molina, M. J.: Air quality in North America's most populous city overview of the MCMA-2003 campaign, Atmos. Chem. Phys., 7, 2447-2473, 2007,

http://www.atmos-chem-phys.net/7/2447/2007/.

Morawska, L. and Zhang, J. F.: Combustion sources of particles. 1. Health relevance and source signatures, Chemosphere, 49, 10451058, 2002.

Moya, M., Ansari, A. S., and Pandis, S. N.: Partitioning of nitrate and ammonium between the gas and particulate phases during the 1997 IMADA-AVER study in Mexico city, Atmos. Environ., 35, 1791-1804, 2001.

Moya, M., Castro, T., Zepeda, M., and Baez, A.: Characterization of size-differentiated inorganic composition of aerosols in Mexico city, Atmos. Environ., 37, 3581-3591, 2003.

Moya, M., Grutter, M., and Baez, A.: Diurnal variability of sizedifferentiated inorganic aerosols and their gas-phase precursors during January and February of 2003 near downtown Mexico city, Atmos. Environ., 38, 5651-5661, 2004.

Mugica, V., Maubert, M., Torres, M., Munoz, J., and Rico, E.: Temporal and spatial variations of metal content in tsp and $\mathrm{PM}_{1} 0$ in Mexico city during 1996-1998, J. Aerosol Sci., 33, 91-102, 2002.

Noble, C. A. and Prather, K. A.: Real-time measurement of correlated size and composition profiles of individual atmospheric aerosol particles, Environ. Sci. Technol., 30, 2667-2680, 1996.

Olmez, I., Sheffield, A. E., Gordon, G. E., Houck, J. E., Pritchett, L. C., Cooper, J. A., Dzubay, T. G., and Bennett, R. L.: Compo- 
sitions of particles from selected sources in philadelphia for receptor modeling applications, Japca J. Air Waste Ma., 38, 1392$1402,1988$.

Ondov, J. M. and Wexler, A. S.: Where do particulate toxins reside? An improved paradigm for the structure and dynamics of the urban mid-Atlantic aerosol, Environ. Sci. Technol., 32, 2547-2555, 1998.

Pastor, S. H., Allen, J. O., Hughes, L. S., Bhave, P., Cass, G. R., and Prather, K. A.: Ambient single particle analysis in Riverside, California by aerosol time-of-flight mass spectrometry during the SCOS97-NARSTO, Atmos. Environ., 37, S239-S258, 2003.

Pitts, J. N., Grosjean, D., Vancauwenberghe, K., Schmid, J. P., and Fitz, D. R.: Photo-oxidation of aliphatic-amines under simulated atmospheric conditions - formation of nitrosamines, nitramines, amides, and photo-chemical oxidant, Environ. Sci. Technol., 12, 946-953, 1978.

Qin, X. Y. and Prather, K. A.: Impact of biomass emissions on particle chemistry during the California regional particulate air quality study, Int. J. Mass Spectrom., 258, 142-150, 2006.

Raga, G. B., Baumgardner, D., Castro, T., Martinez-Arroyo, A., and Navarro-Gonzalez, R.: Mexico city air quality: A qualitative review of gas and aerosol measurements (1960-2000), Atmos. Environ., 35, 4041-4058, 2001.

Reid, J. S., Koppmann, R., Eck, T. F., and Eleuterio, D. P.: A review of biomass burning emissions part II: intensive physical properties of biomass burning particles, Atmos. Chem. Phys., 5, 799825,2005 ,

http://www.atmos-chem-phys.net/5/799/2005/.

Salcedo, D., Onasch, T. B., Dzepina, K., Canagaratna, M. R., Zhang, Q., Huffman, J. A., DeCarlo, P. F., Jayne, J. T., Mortimer, P., Worsnop, D. R., Kolb, C. E., Johnson, K. S., Zuberi, B., Marr, L. C., Volkamer, R., Molina, L. T., Molina, M. J., Cardenas, B., Bernabé, R. M., Márquez, C., Gaffney, J. S., Marley, N. A., Laskin, A., Shutthanandan, V., Xie, Y., Brune, W., Lesher, R., Shirley, T., and Jimenez, J. L.: Characterization of ambient aerosols in Mexico City during the MCMA-2003 campaign with Aerosol Mass Spectrometry: results from the CENICA Supersite, Atmos. Chem. Phys., 6, 925-946, 2006, http://www.atmos-chem-phys.net/6/925/2006/.

Schlesinger, W. H. and Hartley, A. E.: A global budget for atmospheric $\mathrm{nh}_{3}$, Biogeochemistry, 15, 191-211, 1992.

Seibert, P., Kromp-Kolb, H., Baltensperger, U., Jost, D. T., and Schwikowski, M.: Trajectory analysis of high-alpine air pollution data, in, New York, Plenum Press, 1994.

Shields, L. G., Suess D. T. and Prather K.: Determination of single particle mass spectral signatures from heavy-duty diesel vehicle emissions for $\mathrm{PM}_{2} .5$ source apportionment, Atmos. Environ., 41, 3841-3852, 2007.

Silva, P. J., LiuD. Y., Noble C. A. and PratherK. A.: Size and chemical characterization of individual particles resulting from biomass burning of local southern California species, Environ. Sci. Technol., 33, 3068-3076, 1999.

Silva, P. J.: Source profiling and apportionment of airborne particles: A new approach using aerosol time-of-flight mass spectrometry, Dept. of Chem. Riverside, University of California, Riverside, PhD thesis, 2000.

Sodeman, D. A., Toner, S. M., and Prather, K. A.: Determination of single particle mass spectral signatures from light-duty vehicle emissions, Environ. Sci. Technol., 39, 4569-4580, 2005.
Song, X. H., Hopke P. K., Fergenson, D. P., and Prather, K. A.: Classification of single particles analyzed by ATOFMS using an artificial neural network, art-2a, Anal. Chem., 71, 860-865, 1999.

Stohl, A., Forster, C., Frank, A., Seibert, P., and Wotawa, G.: Technical note: The Lagrangian particle dispersion model FLEXPART version 6.2, Atmos. Chem. Phys., 5, 2461-2474, 2005, http://www.atmos-chem-phys.net/5/2461/2005/.

Stone, E. A., Snyder, D. C., Sheesley, R. J., Sullivan, A. P., Weber, R. J., and Schauer, J. J.: Source apportionment of fine organic aerosol in Mexico City during the MILAGRO experiment 2006, Atmos. Chem. Phys., 8, 1249-1259, 2008, http://www.atmos-chem-phys.net/8/1249/2008/.

Suarez, A. E. and Ondov, J. M.: Ambient aerosol concentrations of elements resolved by size and by source: Contributions of some cytokine-active metals from coal- and oil-fired power plants, Energ. Fuel., 16, 562-568, 2002.

Sullivan, R. C., Guazzotti, S. A., Sodeman, D. A., and Prather, K. A.: Direct observations of the atmospheric processing of Asian mineral dust, Atmos. Chem. Phys., 7, 1213-1236, 2007, http://www.atmos-chem-phys.net/7/1213/2007/.

Tolocka, M. P., Lake, D. A., Johnston, M. V., and Wexler, A. S.: Number concentrations of fine and ultrafine particles containing metals, Atmos. Environ., 38, 3263-3273, 2004.

Toner, S. M., Sodeman, D. A., and Prather, K. A.: Single particle characterization of ultrafine and accumulation mode particles from heavy duty diesel vehicles using aerosol time-of-flight mass spectrometry, Environ. Sci. Technol., 40, 3912-3921, 2006.

Toner, S. M., Shields, L. G., Sodeman, D. A., and Prather, K. A.: Using mass spectral source signatures to apportion exhaust particles from gasoline and diesel powered vehicles in a freeway study using UF-ATOFMS, Atmos. Environ., doi:10.1016/j.atmosenv.2007.08.005, 2007.

Vega, E., Mugica, V., Reyes, E., Sanchez, G., Chow, J. C., and Watson, J. G.: Chemical composition of fugitive dust emitters in Mexico city, Atmos. Environ., 35, 4033-4039, 2001.

Vega, E., Reyes, E., Sanchez, G., Ortiz, E., Ruiz, M., Chow, J., Watson, J., and Edgerton, S.: Basic statistics of $\mathrm{PM}_{2} .5$ and $\mathrm{PM}_{1} 0$ in the atmosphere of Mexico city, Sci. Total Environ., 287, 167176, 2002.

Volkamer, R., Jimenez, J. L., San Martini, F., Dzepina, K., Zhang, Q., Salcedo, D., Molina, L. T., Worsnop, D. R., and Molina, M. J.: Secondary organic aerosol formation from anthropogenic air pollution: Rapid and higher than expected, Geophys. Res. Let., 33, L17811, doi:10.1029/2006GL026899, 2006.

Wenzel, R. J., Liu, D. Y., Edgerton, E. S., and Prather, K. A.: Aerosol time-of-flight mass spectrometry during the Atlanta Supersite experiment: 2. Scaling procedures, J. Geophys. Res., 108(D7), 8427, doi:10.1029/2001JD001563, 2003.

Yao, X. H., Fang, M., and Chan, C. K.: Size distributions and formation of dicarboxylic acids in atmospheric particles, Atmos. Environ., 36, 2099-2107, 2002.

Yokelson, R. J., Urbanski, S. P., Atlas, E. L., Toohey, D. W., Alvarado, E. C., Crounse, J. D., Wennberg, P. O., Fisher, M. E., Wold, C. E., Campos, T. L., Adachi, K., Buseck, P. R., and Hao, W. M.: Emissions from forest fires near Mexico City, Atmos. Chem. Phys., 7, 5569-5584, 2007, http://www.atmos-chem-phys.net/7/5569/2007/. 